\title{
Plio-Pleistocene Mediterranean bathyal echinoids: evidence of adaptation to psychrospheric conditions and affinities with Atlantic assemblages
}

\author{
Enrico Borghi, Vittorio Garilli, and Sergio Bonomo
}

\begin{abstract}
Palaeontological evidences of autochthonous deep-water echinoids are so rare that the well-preserved assemblage herein described from the Plio-Pleistocene of Capo Milazzo (NE Sicily) provide an important opportunity to investigate the biodiversity of the bathyal echinoids in the Mediterranean late Cenozoic. The low diversity fauna studied is dominated by Cidaris margaritifera, Histocidaris sicula and Stirechinus scillae, which are species closely related to Recent echinoids today confined to the western Atlantic deep bottoms. The echinoid assemblages of Capo Milazzo and of the Plio-Pleistocene Argille Azzurre Formation (Italy) share a number of species, most of which are known also from shallow water Plio-Pleistocene deposits and the presentday Mediterranean; C. margaritifera is the only strictly bathyal echinoid that occurs in both formations. The palaeoecological study of these echinoids indicates an epibenthic way of life on muddy bottoms, in deep waters with psychrospheric conditions. The following species from the Argille Azzurre are interpreted as strictly bathyal: Histocidaris rosaria, Schizaster braidensis and Schizaster ovatus (transferred into the genus Holanthus). The modern Mediterranean (impoverished) deep-water echinoid assemblage has north-eastern Atlantic affinities and, with the exception of Holanthus expergitus, all the Mediterranean species found at bathyal depth are eurybathic, as they live also in shelf settings. In contrast, the bathyal echinoids of Capo Milazzo show strongest affinities with strictly deep-water western Atlantic species, particularly those of the Caribbean area. They vanished from the Mediterranean during the Quaternary due to the loss of psychrospheric conditions. Based on the Punta Mazza section, dated by nannofossils and data from literature, their stratigraphic range at Capo Milazzo is late Piacenzian-Calabrian.
\end{abstract}

Enrico Borghi, Società Reggiana di Scienze Naturali, Via Tosti, 142100 Reggio Emilia, Italy, e.borghi@corghi.com

Vittorio Garilli (corresponding author), Paleosofia-APEMA Research \& Educational Service, Via Alla

Falconara 3490136 Palermo, Italy, vittoriogarilli@apema.eu, vittorio.garilli@paleosofia.it

Sergio Bonomo, Istituto per l'Ambiente Marino Costiero, Consiglio Nazionale delle Ricerche, Calata Porta di Massa, Interno Porto di Napoli, 80133 Naples, Italy, sergio.bonomo@cnr.it

Keywords: bathyal echinoids; psychrosphere; Atlantic; Mediterranean; Plio-Pleistocene; Sicily

PE Article Number: 17.3.44A

Copyright: Palaeontological Association November 2014

Submission: 3 April 2014. Acceptance: 7 November 2014

Borghi, Enrico, Garilli, Vittorio, and Bonomo, Sergio. 2014. Plio-Pleistocene Mediterranean bathyal echinoids: evidence of adaptation to psychrospheric conditions and affinities with Atlantic assemblages. Palaeontologia Electronica 17.3.44A: 1-26.

palaeo-electronica.org/content/2014/979-cenozoic-deep-water-echinoids 


\section{INTRODUCTION}

Since the early Miocene closure of the communication with the Indo-Pacific Ocean (Harzhauser et al., 2007), the shallow and bathyal Mediterranean fauna consistently, and differently, owes its biodiversity setting to the influence of the Atlantic Ocean. Water interchanges with the Atlantic were interrupted only in the late Miocene, when the Mediterranean underwent a partly or nearly complete desiccation (Ruggieri, 1967; Hsü et al., 1973). Clear examples of the strong link to the eastern Atlantic are represented by repeated immigrations of boreal and western African benthic molluscs into the Mediterranean during the Pleistocene cold (glacial) and warm (interglacial) periods, respectively, although an endemic component played a relevant role in determining biodiversity changes during interglacials (see Garilli, 2011 for an overview). However, the present-day Mediterranean deep fauna is far from rich, and only a few species can be regarded as strictly bathyal or deeper. This is mainly caused by the oligotrophic setting of the deep Mediterranean, due to the high Gibraltar sill that isolates the deep part of the basin (Emig and Geistdoerfer, 2004) and to the high temperature and salinity conditions representing unfavourable settings for the establishment of benthic species with planktotrophic larval development (Bouchet and Taviani, 1992). Whereas flourishing of the bathyal component manifested during the Mediterranean Middle Pleistocene, severe impoverishment of the bathyal Mediterranean benthos occurred during the Würm glaciation when new palaeoceanographical conditions (homeothermy) were established in the Mediterranean in place of the psychrospheric setting (Emig and Geistdoerfer, 2004; Di Geronimo et al., 2005). Within this palaeoceanographical panorama of faunal impoverishment, the echinoid assemblages are no exception. Extant bathyal echinoids are rare in the Mediterranean (Smith and Gale, 2009). The same is true for the fossil record from the same area: only very few autochthonous bathyal assemblages have been recorded, namely only from the middle Miocene of Cyprus and the northern Apennines, Italy (Smith and Gale, 2009). In both cases, however, mainly spatangoid, scavenger species were found. Outside the Mediterranean area the fossil record of autochthonous bathyal echinoid assemblages is even scantier (see Smith and Gale, 2009 for an overview).

Considering the scarcity of information on this group, with particular regard to the deep Mediterranean, the Plio-Pleistocene echinoid-bearing depos- its at Capo Milazzo studied here represent an important opportunity to investigate the biodiversity of the bathyal echinoids from the late Cenozoic. This site (Figure 1), located in north-eastern Sicily, at few kilometres from the town of Messina, exposes strata from a key time in the evolution of the Mediterranean deep fauna. It provides interesting information on the relationships between Atlantic and Mediterranean deep-sea domains after the dramatic biodiversity drop of the Messinian salinity crisis and the renewed establishing of deep-water assemblages after the reopening of the Gibraltar sill at the Miocene/Pliocene boundary. Despite this, few and fragmentary taxonomical-paleoecological studies have been dedicated to the echinoid assemblages from Capo Milazzo: Aradas (1853) and De Stefano (1901) cited loose echinoid fragments. Checchia Rispoli (1916) described and illustrated cidaroid remains and few complete tests of Stirechinus scillae Desor, 1856; more recently Histocidaris sicula Borghi, 1999 was added to the echinoid list of this site. Few fossil remains were also reported from the surroundings of Messina by Scilla (1670) and Checchia Rispoli (1916).

The main objective of this article is to provide an in-depth study of the taxonomy of the bathyal echinoid assemblages from Capo Milazzo, to highlight their relationships with other similar AtlanticMediterranean assemblages and to discuss their palaeoecological and stratigraphical meanings.

\section{Institutional Abbreviations}

Dip.Te.Ris., Museo Paleontologico, Dipartimento per lo Studio del Territorio e delle sue Risorse, Università di Genova, Italy; IGF, Museo di Paleontologia dell'Università di Firenze, Italy; IGUP, Istituto di Scienze della Terra, Università di Parma, Italy; IPUM, Museo del Dipartimento di Paleontologia e dell'Orto Botanico, Università di Modena e Reggio Emilia, Italy; MG, Museo Geologico G. Cortesi di Castell'Arquato (Piacenza), Italy; MGUP, Museo Geologico G.G. Gemmellaro, Università di Palermo, Italy; MPUR, Museo di Paleontologia, Università La Sapienza di Roma, Italy; MSNP, Museo di Storia Naturale e del Territorio, Università di Pisa, Italy; MSNT, Museo Regionale di Storia Naturale di Torino, Italy; NHMW, Naturhistorische Museum, Wien, Austria.

\section{Other Abbreviations}

$\mathrm{D}$, test diameter at the ambitus; $\mathrm{Da}$, diameter of the apical system; Dp, diameter of the peristome; Dr, diameter of the ring (spine); Ds, shaft diameter (spine); $\mathrm{H}$, height; $\mathrm{L}$, length; $\mathrm{nA}$, number of plates 


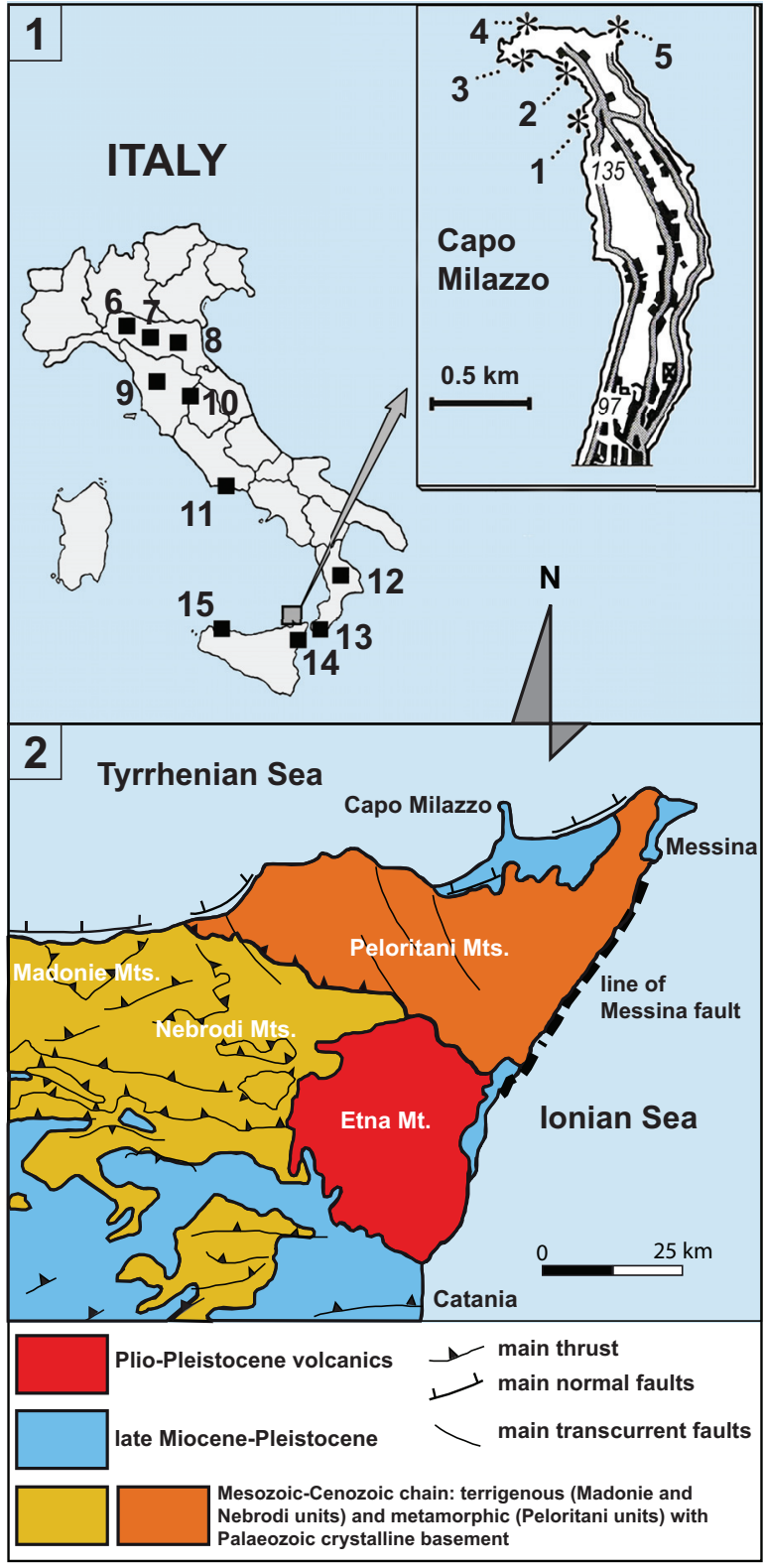

FIGURE 1. Location map (1.1) of the Plio-Pleistocene echinoid-bearing deposits cited in the text and simplified geo-structural sketch (1.2) of NE Sicily (from Antonioli et al., 2006 and Arisco et al., 2006, modified). Capo Milazzo sites: 1, Punta Lazzi; 2, Cala S. Antonio; 3-4, Lighthouse area; 5, Punta Mazza; 6, Bacedasco (Piacenza) and Salsomaggiore (Parma); 7, Quattro Castella and Castellarano (Reggio Emilia); 8, Cianca and Fossetta (Modena); 9, Vescona quarry near Asciano (Siena); 10, Chiusi (Arezzo); 11, Anzio (Rome); 12, Ponte Calderaro and Monte Torre (Catanzaro); 13, Lazzaro and Croce Valanidi (Reggio Calabria); 14, Salice, Coilare and Contrada Petrazza (Messina); 15, Ficarazzi (Palermo). in ambulacral series; nIA, number of plates in interambulacral series; $p p$, pro parte; s.I., sensu latu; T, thickness; W, width. For the meaning of morphological characters the reader is referred to the Echinoid Directory (www.nhm.ac.uk/research-curation / projects/echinoid-directory/index.html). Synonymy lists follow the symbols recommended by Matthews (1973).

\section{MEDITERRANEAN BATHYAL ECHINOFAUNA FROM PLIOCENE TO PRESENT DAYS: AN OVERVIEW}

Sixteen well-established echinoid species have been recorded in the bathyal Mediterranean Plio-Pleistocene (Table 1). Most of them are eurybathic, whereas only Cidaris margaritifera Meneghini, 1862, Cidaris peroni Cotteau, 1877, Histocidaris rosaria (Bronn, 1831), H. sicula Borghi, 1999 and Stirechinus scillae Desor, 1856 can be considered as strictly bathyal echinoids. The last two species are endemic of Sicily and Calabria (Checchia Rispoli, 1916; Colella and D'Alessandro, 1988; Vazzana, 1996; Borghi, 1999). The other species are commonly found in the Argille Azzurre Formation of Italy, Pliocene to Early Pleistocene in age (Meneghini, 1862; Simonelli, 1889; Cotteau, 1895; Botto Micca, 1896; Airaghi, 1901; Stefanini, 1908; Lambert, 1910; Landi, 1929; Cavallo et al., 1986; Borghi, 1999, 2003).

Most of these species are still recorded in the Calabrian (Table 1), especially from the Argille Azzurre Formation, whereas only poor assemblages dated to this age, Cidaris margaritifera, Histocidaris sicula, Stirechinus scillae (Checchia Rispoli, 1916; Borghi, 1999), and C. cidaris, C. margaritifera, Histocidaris rosaria (Checchia Rispoli, 1907; Landi, 1929), have been reported in the deposits of Capo Milazzo and in the bathyal (Sprovieri, 1985) late Early Pleistocene beds of the Sicilian stratotype of Ficarazzi (north-western Sicily), respectively.

At present there is no information on deepsea echinoid assemblages from Mediterranean Pleistocene interglacials. Very likely, as it is the case with many other groups, the oceanographical conditions during interglacials were unfavourable for bathyal echinoids. Even from the Mediterranean Middle Pleistocene, a time slice during which several glaciations occurred, no echinoids records from bathyal environments are preserved, although other groups underwent considerable increase in biodiversity during this time (Emig and Geistdoerfer, 2004). Also the last glaciation period (Würm) was characterized by impoverishment of the Medi- 
TABLE 1. Echinoids recorded in the Mediterranean Pliocene bathyal deposits and their occurrence throughout Mediterranean Miocene to Early Pleistocene. $\dagger$, extinct; ?, doubtful records. Bathymetric ranges of extant populations are from Mortensen $(1928,1943)$, Tortonese (1965, 1977) and Phelan (1970).

\begin{tabular}{|c|c|c|c|c|c|c|}
\hline Species & $\begin{array}{l}\text { Depth range } \\
(\mathrm{m})\end{array}$ & 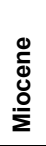 & 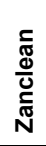 & 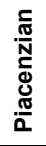 & $\begin{array}{l}\frac{5}{\pi} \\
\frac{\pi}{9} \\
\frac{\pi}{0} \\
0\end{array}$ & $\begin{array}{l}\frac{\pi}{\frac{\pi}{2}} \\
\frac{0}{\frac{\pi}{\pi}} \\
0\end{array}$ \\
\hline $\begin{array}{l}\text { Cidaris cidaris } \\
\text { (Linnaeus, 1758) }\end{array}$ & $50-2000$ & $x$ & $x$ & $x$ & $x$ & $x$ \\
\hline $\begin{array}{l}\text { † Cidaris margaritifera } \\
\text { Meneghini, } 1862\end{array}$ & deeper than 200 & & $x$ & $x$ & $x$ & $x$ \\
\hline $\begin{array}{l}\text { † Cidaris peroni } \\
\text { Cotteau, } 1877\end{array}$ & deeper than 200 & & $x$ & $x$ & $x$ & $x$ \\
\hline $\begin{array}{l}\text { Stylocidaris affinis } \\
\text { (Philippi, 1845) }\end{array}$ & $30-1000$ & & & & $x$ & $x$ \\
\hline $\begin{array}{l}\text { † Histocidaris rosaria } \\
\text { (Bronn, 1831) }\end{array}$ & deeper than 200 & $x$ & $x$ & $x$ & $x$ & $x$ \\
\hline $\begin{array}{l}\text { Histocidaris sicula } \\
\text { Borghi, } 1999\end{array}$ & deeper than 200 & & & $x$ & $x$ & $x$ \\
\hline $\begin{array}{l}\text { Echinus acutus } \\
\text { Lamarck, } 1816\end{array}$ & $20-1400$ & & & $x$ & $x$ & $x$ \\
\hline $\begin{array}{l}\text { Echinus melo } \\
\text { Lamarck, } 1816\end{array}$ & $25-1100$ & & & & $x$ & $x$ \\
\hline $\begin{array}{l}\text { † Stirechinus scillae } \\
\text { Desor, } 1856\end{array}$ & deeper than 200 & & & $x$ & $x$ & $x$ \\
\hline $\begin{array}{l}\text { Genocidaris maculata } \\
\text { Agassiz, } 1869\end{array}$ & $12-500$ & $x$ & $x$ & $x$ & $x$ & $x$ \\
\hline $\begin{array}{l}\text { Echinocyamus pusillus } \\
\text { (Müller, 1776) }\end{array}$ & $0-1250$ & $x$ & $x$ & $x$ & $x$ & $x$ \\
\hline $\begin{array}{l}\text { † Schizaster braidensis } \\
\text { Botto Micca, } 1896\end{array}$ & deeper than 200 & & $x$ & $x$ & $x$ & $?$ \\
\hline $\begin{array}{l}\text { Spatangus purpureus } \\
\text { (Müller, 1776) }\end{array}$ & $15-900$ & $x$ & $x$ & $x$ & $x$ & $x$ \\
\hline $\begin{array}{l}\text { Brissopsis atlantica } \\
\text { Mortensen, } 1913\end{array}$ & $100-3200$ & & & $x$ & $x$ & $x$ \\
\hline $\begin{array}{l}\text { Brissopsis lyrifera } \\
\text { Forbes, } 1841\end{array}$ & $5-1500$ & $x$ & $x$ & $x$ & $x$ & $x$ \\
\hline $\begin{array}{l}\text { † Holanthus ovatus } \\
\text { (Sismonda, 1842) }\end{array}$ & deeper than 200 & & $x$ & $x$ & $x$ & $?$ \\
\hline
\end{tabular}

terranean deep-sea fauna. For instance, most of the Pliocene cold-stenothermal corals were already absent in the Würm deposits (Vertino, 2004) and echinoid records are lacking completely.

In contrast to other deep-sea basins, the present day Mediterranean has a very impoverished echinoid assemblage confined to bathyal depths. The sole Mediterranean strictly bathyal echinoid species is the eurythermal Holanthus expergitus (Lovén, 1874), which is able to adapt to the relatively high temperatures occurring in the deep Mediterranean and to the colder Atlantic conditions, down to $3120 \mathrm{~m}$, where waters become increasingly cooler with depth. The rarity of this species in the Mediterranean (Tortonese, 1977; Koukouras et al., 2007) indicates that it is currently living in extreme environmental conditions in this sea, in relation to its ecological requirements. All the other echinoids found at bathyal depth in the Mediterranean (as well as in the Atlantic) are definitely eurybathic species as they live also in shelf settings (at least up to 100-150 m depth, Table 2).

\section{GEOLOGICAL SETTING}

As part of the southern margin of the Tyrrhenian microplate (Gvirtzman and Nur, 1999), the north-eastern part of Sicily underwent a complicated geo-structural history (Figure 1.2). Most of this area belongs to the Peloritani domain, a thrust fold belt consisting of Hercynic basement covered by Meso-Cenozoic sedimentary deposits. The Peloritani units overthrusted the Apennine-Maghrebide units during the late Oligocene-Miocene, forming a south-vergent thrust belt as a result of the Africa-Europe collision and north-westerly subduction and roll-back of the Adriatic-Ionian slab. From the late Miocene the formation of an extensional fault system manifested as the result of the opening of the Tyrrhenian Basin. Extensional and compressive tectonics occurred in the northern Peloritani area during the Plio-Pleistocene. Consequently, sedimentary deposits accumulated in the subsiding basins were in turn uplifted and disrupted (Di Stefano et al., 2012 and references therein).

In the surroundings of the Straits of Messina the intense and continuous tectonic activity forced some deposits to lift up even more than 1,000 m. An exemplary case of intense uplift is that of the Middle-Late Pleistocene epi-mesobathyal deposits at Contrada Zura, at few kilometres west from Capo Milazzo (Di Geronimo et al., 2005; Sciuto and Rosso, 2008; Di Stefano et al., 2012). Therefore, the Plio-Pleistocene bathyal facies, rarely exposed elsewhere, crop out in this area.

Along the Tyrrhenian coast of eastern Sicily, between Capo Milazzo and Messina, and on both the northern shores of the Straits of Messina, the Pliocene sequences are characterized by a complex palaeotopography, with submerged highs and narrow depressions (Fois, 1990a, 1990b). The Pliocene sediments were deposited on the metamorphic basement, sometimes with the interposition of a Miocene conglomerate, which is Messinian in age at Capo Milazzo (Gaetani and Saccà, 1984; Fois, 1990a, 1990b). Whereas in Sicily the basal part of the Pliocene is often represented by the Trubi Formation, namely white marls 
TABLE 2. Echinoids recorded in the present Mediterranean deep waters (below $250 / 300 \mathrm{~m}$ depth), their bathymetric and Atlantic geographical distribution (Kohler, 1927; Tortonese, 1965, 1977).

\begin{tabular}{|c|c|c|c|}
\hline Species & $\begin{array}{l}\text { Total depth range } \\
\text { (highest } \\
\text { abundance) }(\mathrm{m})\end{array}$ & Bottom & Atlantic distribution \\
\hline $\begin{array}{l}\text { Cidaris cidaris } \\
\text { (Linnaeus, 1778) }\end{array}$ & $\begin{array}{l}50-2000 \\
(60-200)\end{array}$ & mainly mud & Eastern Atlantic: from Norway to Cape Verde. \\
\hline $\begin{array}{l}\text { Stylocidaris affinis } \\
\text { (Philippi, 1845) }\end{array}$ & $30-1000$ & $\begin{array}{l}\text { algal prairies, coralligenous } \\
\text { and mud }\end{array}$ & $\begin{array}{l}\text { Eastern Atlantic: from North-Western Africa to Cape Verde } \\
\text { Islands. } \\
\text { Western Atlantic: from Bermuda Is. to Antilles. }\end{array}$ \\
\hline $\begin{array}{l}\text { Genocidaris maculata } \\
\text { Agassiz, } 1869\end{array}$ & $12-500$ & coralligenous and mud & $\begin{array}{l}\text { Eastern Atlantic: Western Africa, Azores Is. } \\
\text { Western Atlantic: North American coasts. }\end{array}$ \\
\hline $\begin{array}{l}\text { Echinus acutus } \\
\text { Lamarck, } 1816\end{array}$ & $\begin{array}{l}20-1400 \\
(100-400)\end{array}$ & mainly mud & Eastern Atlantic: from Iceland to Angola. \\
\hline $\begin{array}{l}\text { Echinus melo } \\
\text { Lamarck, } 1816\end{array}$ & $\begin{array}{r}25-1100 \\
(30-50)\end{array}$ & $\begin{array}{l}\text { hard and soft (mud) } \\
\text { substrates }\end{array}$ & Eastern Atlantic: from Iceland to Cape Verde. \\
\hline $\begin{array}{l}\text { Neolampas rostellata } \\
\text { Agassiz, } 1869\end{array}$ & $95-1260$ & detritus & $\begin{array}{l}\text { Eastern Atlantic: from the Bay of Biscay to Morocco. Western } \\
\text { Atlantic: Caribbean. }\end{array}$ \\
\hline $\begin{array}{l}\text { Echinocyamus pusillus } \\
\text { (Müller, 1776) }\end{array}$ & $\begin{array}{l}0-1250 \\
(20-40)\end{array}$ & coarse bioclastic sand & Eastern Atlantic: from Norway to Sierra Leone. \\
\hline $\begin{array}{l}\text { Spatangus purpureus } \\
\text { (Müller, 1776) }\end{array}$ & $\begin{array}{l}15-900 \\
(20-40)\end{array}$ & coarse sands and mud & Eastern Atlantic: from Iceland to Angola. \\
\hline $\begin{array}{l}\text { Echinocardium flavescens } \\
\text { (Müller, 1776) }\end{array}$ & $\begin{array}{l}5-360 \\
(30-40)\end{array}$ & sand, mud and detritus & Eastern Atlantic: from Iceland to Portugal and Azores. \\
\hline $\begin{array}{l}\text { Brissopsis atlantica } \\
\text { Mortensen, } 1913\end{array}$ & $100-3200$ & mainly mud & $\begin{array}{l}\text { Eastern Atlantic: Western Africa. } \\
\text { Western Atlantic: North American coasts. }\end{array}$ \\
\hline $\begin{array}{l}\text { Brissopsis lyrifera } \\
\text { Forbes, } 1841\end{array}$ & $5-1500$ & mainly mud & $\begin{array}{l}\text { Eastern Atlantic: from Norway to Sierra Leone and Southern } \\
\text { Africa. }\end{array}$ \\
\hline $\begin{array}{l}\text { Holanthus expergitus } \\
\text { (Lovén, 1874) }\end{array}$ & $400-3120$ & mud & $\begin{array}{l}\text { Eastern Atlantic: from Iceland to Cape Verde and Azores } \\
\text { Islands. } \\
\text { Western Atlantic: from Davis Strait to Antilles. }\end{array}$ \\
\hline
\end{tabular}

rich in planktonic foraminifers (Ogniben, 1957, 1975), at Capo Milazzo the early Pliocene strata consist of thin micritic layers with condensed faunas (MPI1-MPI2 Biozones), or of infilling of small fractures within the early Messinian carbonate basal complex (Fois, 1990a, 1990b). They represent epibathyal deposits characterised by low sedimentary rate. Coarser facies rich in macro benthos, mainly made by yellow calcareous marls, are present upwards. They yield an abundant macrofauna and provided most of the examined echinoids. These sediments are only a few tens of meters thick and are attributed to the very late Piacenzian-Gelasian MPI 5 and MPI 6 biozones (Fois, 1990 a, 1990b). Towards the top they gradually pass to grey clayey marls, attributed to the Early and Middle Pleistocene (Violanti, 1988). They are rich in hermatypic scleractinian corals (a characteristic component of the extant white corals bathyal biocoenosis) often recorded in Sicily within the bioclastic marls or directly installed on the rocky substrate. This facies is not frequent at Capo Milazzo: it is recognised above all in the vertical fractures of the metamorphic basement and of the Miocene limestone underlying the base of the Pliocene succession (Fois, 1990a, 1990b).
Late Pleistocene (Tyrrhenian) conglomerates occur at the top of the succession; they are almost sub-horizontal and lay in discordance over the marls/mudstones. The molluscan fauna from these deposits mainly consists of species still occurring in the Mediterranean (Ruggieri and Greco, 1965).

\section{MATERIALS AND METHODS}

As a whole, the material studied from the PlioPleistocene of Capo Milazzo consists of 220 specimens: 115 of them have been recovered by hand picking and sieved bulk samples collected in 1998 and 2004 by the first author. Sixty-five specimens, examined in private collections (S. Bertolaso, Reggio Emilia, S. Palazzi, Modena and A. Villari, Messina) are now housed at MG, as well as the type material of Histocidaris sicula and all the other specimens collected by the first author. This material consists of isolated spines and plates, and complete coronas, two of them still bearing jaws and spines. Forty-one additional specimens from Capo Milazzo and the surroundings of Messina were examined in the Checchia Rispoli collection at MGUP. The specimens described by Landi (1929) and Vinassa De Regny (1897) are housed 


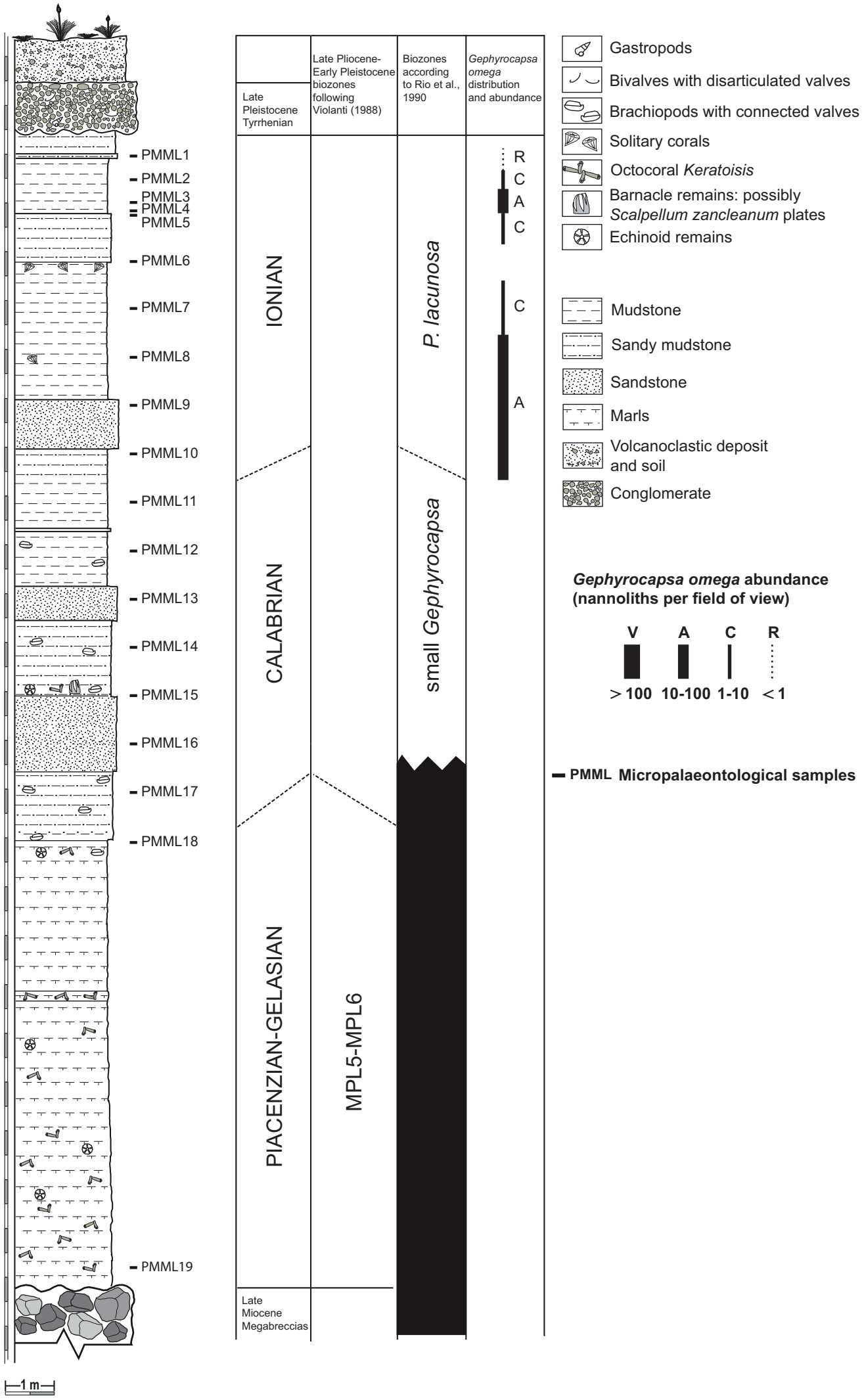

FIGURE 2. Simplified evolution of the Punta Mazza section (Capo Milazzo, NE Sicily, Italy) with stratigraphy by means of calcareous nannofossils (this study) and Violanti (1988). 
at IPUM and IGUP, respectively. The Checchia Rispoli collection of the echinoids from Anzio (central Italy), including the holotype of Cidaris cerullii, was studied at MPUR. The specimens described by Airaghi (1901) from the Pliocene bathyal clays of Liguria (northern Italy) were examined at Dip.Te.Ris.

In order to provide an exhaustive overview of the available Mediterranean Plio-Pleistocene deepwater echinoids, a further 142 specimens, from the Argille Azzurre Formation of Emilia (northern Italy) and Tuscany (central Italy), and from Sicily and Calabria (southern Italy), have been examined at MG. This Formation is dated to the interval Zanclean (p.p.) to Early Pleistocene (p.p.). In particular, the basal unit is referable to the early Zanclean Sphaeroidinellopsis seminulina s.l. Zone in Tuscany and Romagna and to the middle Zanclean Globorotalia margaritae Zone (MPI2 Biozone) in Piedmont and Emilia (Dela Pierre et al., 2003). The top of the Formation has been attributed to the Piacenzian in Tuscany (Globorotalia aemiliana and Discoaster tamalis Zones; Lazzarotto et al., 2002) and Piedmont (Globorotalia puncticulata Zone; Dela Pierre et al., 2003), whereas it is Early Pleistocene in Emilia Romagna (Helicosphaera sellii Zone and first appearance of Hyalinea balthica; Raffi and Rio, 1980). These clays deposited in the upper part of the epibathyal zone or at least in the deeper outer neritic zone (Lazzarotto et al., 2002).

\section{The Sampling Sites at Capo Milazzo}

The material collected at Capo Milazzo comes from the sections cropping out at Cala S. Antonio, Lighthouse, Punta Lazzi and Punta Mazza (Figure 1.1). Most of these sites are known to palaeontological literature, particularly in regard to deepwater taxa such as brachiopods (Gaetani and Saccà, 1984), corals (Vertino, 2004), foraminifers (Violanti, 1988), molluscs (Palazzi and Villari, 1996) and ostracods (Sciuto, 2003). Geological information was provided by Seguenza (1873-77), Cortese (1882), Baldacci (1886), Lipparini et al. (1955), Ruggieri and Greco (1965), Ruggieri (1967), Violanti (1988) and Fois (1990a, 1990b).

The Cala S. Antonio (or S. Antonino) section is $13.5 \mathrm{~m}$ thick (Sciuto, 2003) and extends laterally for more than a hundred meters. From the bottom upwards, it is formed by whitish marls rich in foraminifers, but without echinoid remains, and is attributed to the early Pliocene (Fois, 1990a, 1990b); biocalcarenites and yellow calcareous marls, rich in macrofossils, are referred to the biozones MPI 5 and MPI 6 (Violanti, 1988; Sciuto,
2003), late Pliocene-Early Pleistocene according to the recently ratified, two-fold, Plio-Pleistocene stratigraphy (Gibbard et al., 2010); a Late Pleistocene (Tyrrhenian) conglomerate with shallow-water echinoids forms the top of this section.

The Lighthouse section is formed by low marly outcrops scattered along the western coast of the Capo Milazzo Peninsula. It corresponds to the sites 2, 3 and 8 described by Fois (1990a, figure 1). The fossil assemblage is similar to that cropping out at Cala $\mathrm{S}$. Antonio but less rich in echinoid remains. Sediments from this section belong to the biozones MPI 5 and MPI 6 (Fois, 1990a).

The lens-shaped outcrop at Punta Lazzi extends laterally for a few hundred meters, filling a depression of the pre-Pliocene metamorphic basement. Gaetani and Saccà (1984) recognised from the bottom upwards: carbonate-cemented conglomerates, 2-10 m thick, lying on the metamorphic basement; up to $6 \mathrm{~m}$ thick pinkish coarse micrite, almost sterile, early Pliocene in age; $8 \mathrm{~m}$ thick yellowish calcareous marls, referred to biozones MPI 5 and MPI 6 by Violanti (1988), rich in planktonic foraminifers and macrofossils (gorgonacea, cirripeds, brachiopods, bivalves, teeth of sharks and most of the examined echinoids); $2.5 \mathrm{~m}$ thick grey sandy marls yielding bathyal brachiopods, colonial corals and echinoids, Calabrian in age (Palazzi and Villari, 1996); conglomerates bearing a Late Pleistocene (Tyrrhenian) fauna also containing shallow-water echinoids.

The section at Punta Mazza (Figures 2, 3) is the most representative late Cenozoic outcrop in the Capo Milazzo Peninsula, especially for the Pleistocene. The base of this section is formed by large breccias, late Miocene in age (Fois, 1990a, $1990 \mathrm{~b})$; these are covered by about $9 \mathrm{~m}$ thick yellowish marls bearing echinoid remains, Keratoisis octocorals and brachiopods with articulated valves. The upper part (about $14 \mathrm{~m}$ thick) mainly consists of mudstone and sandy mudstone, somewhat marly and yellowish in the lower part, intercalated by few sandstone layers. At its base, this part is characterized by echinoids, brachiopods, octocorals and barnacle remains; solitary corals and small molluscs prevail in the upper portion. The top of the section is formed by about $1 \mathrm{~m}$ thick Tyrrhenian conglomerate with poorly preserved littoral molluscan assemblages. The conglomerate is separated by an erosion surface from the muddy sediments and is covered by volcanoclastic deposits forming soil. According to Violanti (1988) the lower, marly part of the section can be attributed to the late Pia- 


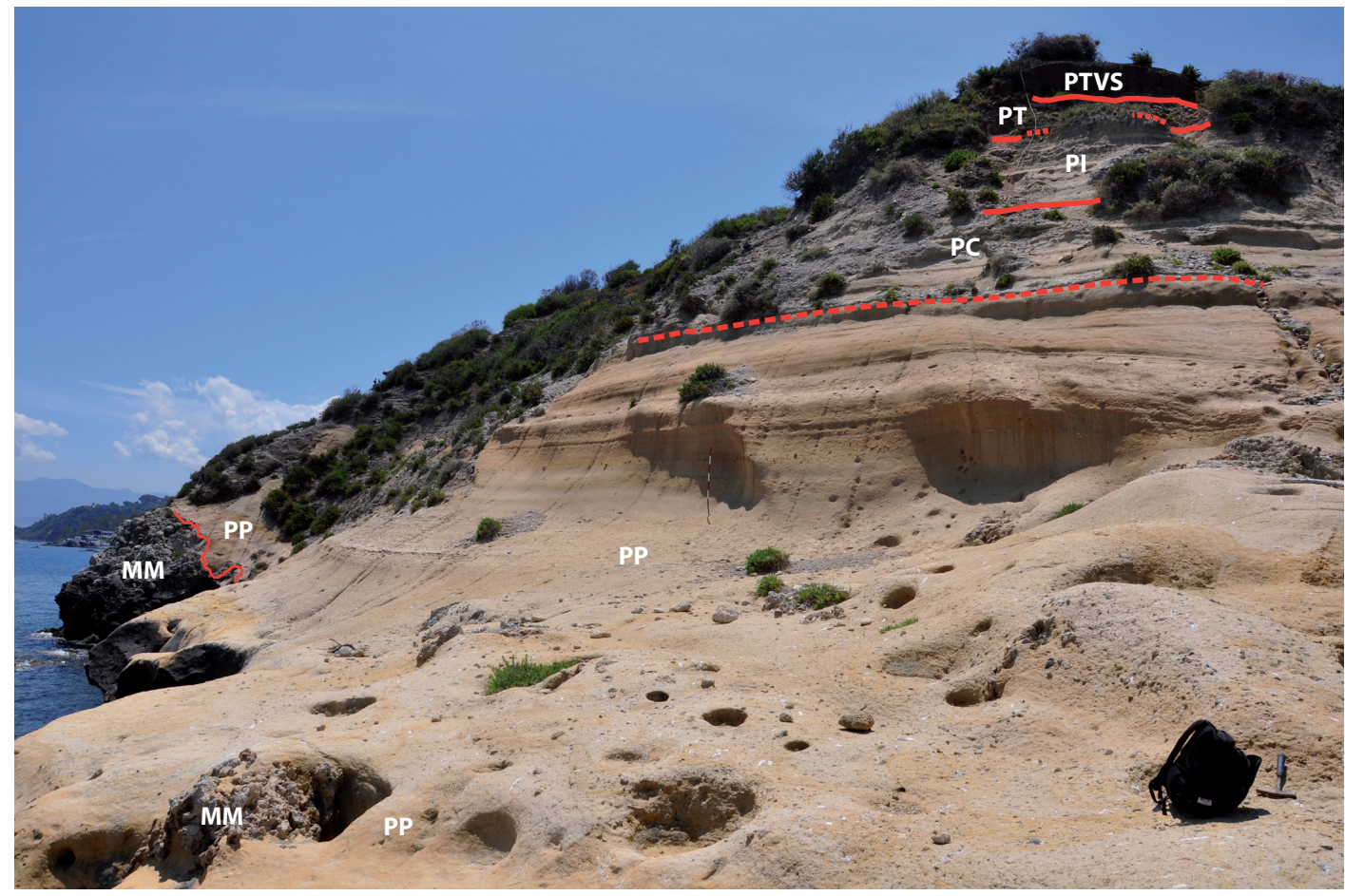

FIGURE 3. The Punta Mazza section at Capo Milazzo (NE Sicily, Italy). MM, late Miocene Megabreccias; PP, Pliocene-Early Pleistocene (Gelasian) marls, following Violanti (1988); PC, Pleistocene, Calabrian; PI, Pleistocene, Ionian; PT, Late Pleistocene (Tyrrhenian) conglomerate; PTVS, post Tyrrhenian volcaniclastic deposit and soil.

cenzian to Gelasian biozones MPI 5 and MPI 6, whereas the muddy part is dated as Calabrian (small Gephyrocapsa zone). At this section calcareous nannofossils were studied in order to provide a stratigraphical setting for echinoid occurrences. For this purpose, a total of 19 samples (PMML 119 , Figure 2) were collected along this outcrop and analysed. Sample spacing varied from values of few centimetres to $1 \mathrm{~m}$ in the upper part of the succession; an isolated sample was collected in the basal part. Smear slides were prepared from unprocessed sediment according to standard technique (Bown and Young, 1998) and analysed under a polarized light microscope at 1000X magnification. The abundance of calcareous nannofossils for each sample was estimated as follows: $V$ (very abundant) $=>100$ nannoliths per field of view; $A$ (abundant) $=10-100$ nannoliths per field of view; $C$ (common) $=1-10$ nannoliths per field of view; $R$ (rare) $=<1$ nannolith per 10 fields of view. Main results are presented in Figure 2.

\section{RESULTS}

\section{The Nannofossil Assemblage}

The species involved in this study are mainly included within the family Noelaerhabdaceae, retic- ulofenestrids including the genera Pseudoemiliania Gartner, 1969, Gephyrocapsa Kamptner, 1943 and Reticulofenestra Hay et al., 1966 (Thierstein et al., 1977; Pujos-Lamy, 1977; Wei, 1993; Raffi et al., 1993; Weaver and Thomson, 1993). However, the taxonomy of this group is complex and confusing, mainly due to a proliferation of species names and morphotypes. Here we adopted the concepts of Raffi et al. (1993) and Flores et al. (2000) for the morphological features of gephyrocapsids, using coccolith diameter, bridge angle, etc., which are readily identifiable under cross-polarized light.

Calcareous nannofossils are generally abundant to common throughout the section. Large to small size coccoliths of the genera Calcidiscus Kamptner, 1950, Gephyrocapsa, Helicosphaera Kamptner, 1954, Pseudoemiliania and Reticulofenestra are the most common components of the nannofossil assemblage in the studied section. Reworked taxa occur throughout the section in medium to high frequency. Preservation is moderate to good in marly/muddy layers, but is poor to very poor in the sandy levels, with partially dissolved and/or overgrown assemblages.

The present results mainly focus on semiquantitative distributions of $P$. lacunosa (Kamptner, 1963) ex Gartner, 1969, R. asanoi Sato and 
Takayama, 1992, small Gephyrocapsa and G. omega Bukry, 1973, which are major components of the investigated Pleistocene calcareous nannofossil assemblage. The studied interval corresponds to the transitional record through the small Gephyrocapsa and P. lacunosa zones of Rio et al. (1990). The recognized calcareous nannofossil event is the first occurrence (FO) of G. omega, between samples PMML 10 and 11, which allows approximation of the Calabrian/Ionian transition (Figure 2).

FO of G. omega is a well recognized event in the studied section and defines the small Gephyrocapsa and P. lacunosa zonal boundary (Rio et al., 1990). With regard to the available biochronological data set, the Middle Pleistocene reappearance of medium-sized Gephyrocapsa is known to be consistently diachronous at different latitudes, between MIS 29 and 25, and is considered as a possible migration event from low to mid-high latitudes (Wei, 1993; Raffi et al., 1993; Flores et al., 1999; Raffi, 2002). In the Mediterranean, the event is consistently recorded in the interval between MIS 26 and MIS 25 (Castradori, 1993; de Kaenel et al., 1999; Raffi, 2002; Maiorano et al., 2004).

\section{Systematic Palaeontology}

We follow the systematics proposed by Kroh and Smith (2010).

Family CIDARIDAE Gray, 1825

Sub-family CIDARINAE Gray, 1825

Genus CIDARIS Leske, 1778

Type species. Echinus cidaris Linnaeus, 1758, by subsequent designation of Mortensen (1910).

Remarks. The main difference between Cidaris Leske, 1778 and the closely related genera regards the shape of the pedicellariae, which are rarely available in fossil specimens. Thus, the attribution of fossil echinoids to Cidaris is problematic. Notwithstanding this, on the basis of other relevant characters, we prefer to consider the following species within Cidaris s.l. following Mortensen's (1928) opinion: "we must go on designating such fossil forms, of uncertain generic placement, simply as Cidaris, but... Cidaris here is meant in a broad sense, not in the restricted sense of the recent genus Cidaris."

Cidaris cerullii (Checchia Rispoli, 1923)

Figure 4.31-32

V* 1923 Dorocidaris cerullii Checchia Rispoli, pp. 9-10, pl. 2, figs. 5-8.

1925 Dorocidaris cerullii Checchia Rispoli; Lambert and Thiery, p. 560.
1968 Cidaris (?) cerullii (Checchia Rispoli); Menesini, pp. 584-587.

v. 2003 Cidaris cerullii (Checchia Rispoli); Borghi, pp. 115-117, pl. 2, figs. 7-8; pl. 3, fig. 1.

Material. A test fragment (Figure 4.31) made of four interambulacral plates in connection and the adjoining ambulacral plates (MG.1033.34). Calcareous marls, very late Piacenzian-Gelasian of Punta Lazzi.

Comparative material. The holotype (MPUR.i30), two test fragments and two primary spines from the Pliocene of Anzio. Two test fragments and two primary spines from the Gelasian of the Stirone River, near Parma (MG.1068).

Remarks and comparison. The large interambulacral median areas, the multiple (3-4) regular vertical series of almost equal-sized tubercles in the ambulacrum (Figure 4.32), the scrobicular rings covering the whole height of the plates and the lack of crenulation on the primary tubercles are the main characters allowing separation from C. margaritifera. Also, in $C$. cerullii the interambulacral plates have a higher width/height ratio at the ambitus: 1.6-1.8 in the specimen from Punta Lazzi, 1.71.9 in the holotype and 1.1-1.2 in C. margaritifera.

Distribution. Very rare in the Gelasian of Capo Milazzo. Pliocene of Anzio and Calabrian of Monte Mario, near Rome (Checchia Rispoli, 1923). Pliocene of southern Italy, at Punta Ristola, near Lecce (Menesini, 1968), and Gelasian of Emilia Romagna (Borghi, 2003).

\section{Cidaris margaritifera Meneghini, 1862}

Figure 4.1-7, 4.10-30

1862 Cidaris margaritifera Meneghini, pp. 19-21, pl. 2, figs. 12-13.

1901 Leiocidaris margaritifera (Meneghini); De Stefano, p. 7.

v. 1916 Dorocidaris margaritifera (Meneghini); Checchia Rispoli, p. 230, pl. 26, figs. 1-27.

v. 1929 Dorocidaris margaritifera (Meneghini); Landi, p. 11, pl. 1, figs. 8a, b-9a, b.

vp.1999 Cidaris peroni Cotteau; Borghi, pp. 107110, pl. 2, figs. 1-5 and 11.

Material. Three complete interambulacra with attached half-ambulacra and four test fragments, 27 interambulacral plates and 68 primary spines (MG.1032, 1033, 1035). Eight test fragments and 26 primary spines (MGUP, with no catalogue number), from the late Piacenzian, Gelasian and Calabrian of Capo Milazzo. Topo-typical material from the Pliocene of Tuscany: one plate and two spines (MG.1034.05) from Chiusi (Arezzo), four interam- 




Figure 4 (see next page for caption). 
bulacral plates and 51 spines (MG.1034.04 and MG.1035.50) from Asciano near Siena. Two complete segments, 11 primary spines and three genital plates, Early Pleistocene of Calabria and Sicily (southern Italy): Lazzaro (MG.1032.01; MG.1034.12-13) and Croce Valanidi (MG.1034.13) (Reggio Calabria), Ponte Calderaro (Catanzaro; MG.1032-07) and Venetico Marina (Messina; MG.1033.40). Specimens from the Pliocene of Emilia (northern Italy): 12 primary spines from Cianca and Fossetta near Modena (IPUM, with no catalogue number); six primary spines from Bacedasco near Piacenza (IGUP, with no catalogue number); 28 primary spines and 1 interambulacral plate (MG.1035.51-53, MG1078, MG.1084) from Salsomaggiore (Parma), Castellarano and Quattro Castella (Reggio Emilia).

Description. Test sub-globular, slightly flattened above and below. The largest complete segment (Figure $4.1 ; \mathrm{H}=46 \mathrm{~mm}$ ) indicates a diameter of the whole corona up to $60 \mathrm{~mm}$.

Ambulacra. Pair pores not conjugate, separated by a narrow interporal partition. Attachment area poorly developed and pores closely spaced. Pores zones rather sunken. Two regular series of marginal tubercles and two of inner tubercles present in adult specimens at the ambitus (Figure 4.19). No naked zone along the perradius.

Interambulacra. Plates almost as wide as high at the ambitus (Figure 4.1-2). Primary tubercles perforate. Crenulation on first, rarely on second, adapical plates in each series; crenulation weak and usually limited to the aboral edge of tubercle (Figure 4.1). Scrobicular rings rather prominent, extending to upper and lower edges of plates. Extrascrobicular zone narrow, with fairly large and prominent secondary tubercles. Adapically, tubercles often arranged in horizontal rows, separated by furrows (Figure 4.19). Sutures incised, not naked. Ambitally areoles well separated, only the adoral most two plates are confluent (Figure 4.2). A rudimentary tubercle (Figure 4.1 ) is present on the first, in largest specimens also on the second, adapical plates.

Primary spines. Tapering to the tip and terminating in a small crown-like whorl of small thorns; fan-shaped terminations rare. Short primary spines stout, with rounded tip (Figure 4.28 ) and crenulate base. Spines may be

FIGURE 4 (see left). Species of the genus Cidaris Leske, 1778 from the Plio-Pleistocene of Capo Milazzo (4.1-7, 4.10$16,4.19,4.24,4.27-28,4.30-32)$ and Italy mainland $(4.17-18,4.20-23,4.25-26,4.29)$, and from the Recent site off Gallipoli, Ionian Sea (4.8-9). Cidaris margaritifera (Meneghini, 1862) from the uppermost Piacenzian-Gelasian and Calabrian of Capo Milazzo. 4.1, lateral view of a complete segment (MG.1033.39) with only the first fully developed adapical tubercles bearing crenulation, $\mathrm{W}=13 \mathrm{~mm}$; Cala $\mathrm{S}$. Antonio; 4.2, oblique view of a complete segment (MG.1033.41) with only the two last adoral plates confluent; $W=25 \mathrm{~mm}$, Punta Lazzi; 4.3, complete, fusiform spine (MG.1035.31) with almost smooth ridges, L=43 mm, Punta Lazzi; 4.4, complete, fusiform, non-crenulate spine (MG.1035.32) with fine spinules, L=52 mm, S. Antonio; 4.5, non-crenulate spine (MG.1032.68) with small granules, L=22 mm, Punta Lazzi; 4.6, cylindrical spine (MG.1032.69) with almost smooth ridges, L=24 mm, S. Antonio; 4.7, cylindrical spine (MG.1035.33) with low ridges bearing fine spinules; base partially crenulate, L=50 mm, S. Antonio; 4.10 , close up of a spine (MG.1032.53) with smooth ridges, Ds=1.7 mm, S. Antonio; 4.11, close up of a spine (MG.1032.54) with low and sharp spinules, Ds=2.4 mm, S. Antonio; 4.12, spine (MG.1032.55) with granules, Ds=2.5 mm, S. Antonio; 4.13, crenulate spine (MG.1032.57) with ridges bearing small granules, Ds=4.2 mm, S. Antonio; 4.14, spine (MG.1032.58) with prominent spinules, Ds=4.8 mm, S. Antonio; 4.15, spine (MG.1032.62) with low spinules and space between rows covered by spongy coat, and close up view (4.16) of the non-crenulate acetabulum rim, Ds=4.8 mm, S. Antonio; 4.19 , close up view of a poriferous area (MG.1032.06), Punta Lazzi; 4.24, section of a primary spine (MG.1032.38), Ds=4.6 $\mathrm{mm}$, Punta Lazzi; 4.27, fusiform, partially crenulate spine (MG1032.51) with spongy coat still visible between ridges; Ds=5.8 mm, Punta Lazzi; 4.28, short and stout primary spine (MG.1033.38); L=17 mm, Punta Lazzi. Cidaris cidaris (Linnaeus, 1778), complete test, $D=42$ mm (MG.1033.36); Recent, Gallipoli (Puglia), depth: 55 m. 4.8, adoral view; 4.9, close up of a crenulate adapical tubercle. Cidaris margaritifera (Meneghini, 1862) from Italy mainland. 4.17, frontal view of a complete segment, $\mathrm{H}=46 \mathrm{~mm}$, Tmax $=4 \mathrm{~mm}$ at ambitus (MG.1032.01), Calabrian of Lazzaro (Reggio Calabria), 4.18, lateral view; 4.20, primary spine; Ds=3.9 mm; Pliocene, Fossetta (Modena), Landi collection (IPUM); 4.21, primary spine with rounded grains, Ds= $4.2 \mathrm{~mm}$, Pliocene, Cianca (Modena), Landi collection (IPUM), and close up view of the smooth acetabulum rim (4.22); 4.23, close up of a spine with prominent spinules, Ds=4.3 mm (MG.1078.02), Piacenzian, Quattro Castella (Reggio Emilia); 4.25, primary spine with thorns and close up view of the partially crenulate acetabulum (4.26), Ds=3.7 mm (MG.1034.04), early Pliocene, Vescona quarry near Asciano (Siena); 4.29, interambulacral plate, $W=14.8 \mathrm{~mm}, \mathrm{~T}=4 \mathrm{~mm}$ (MG.1034.05), early Pliocene, Chiusi (Arezzo), with lateral view (4.30). Cidaris cerullii (Checchia Rispoli, 1923), (MG.1033.34), Gelasian of Punta Lazzi. 4.31, test fragment, $\mathrm{H}=36 \mathrm{~mm}$; with 4.32, close up of the ambulacral area. Scale bars equal $2 \mathrm{~mm}$. 
slightly swollen under the neck. Collar well marked, short, with length/diameter ratio of $0.3-0.7$. Ring slightly prominent. Neck well developed with smooth, glossy surface, usually longer than the collar. Collar, ring and base longitudinally finely striate. Shaft cylindrical to fusiform, with Ds up to 8.7 $\mathrm{mm}$ in examined sample. Shaft ornamentation very variable: there may be rows made by conical thorns (Figure 4. 14), fine and sharp spinules (Figure 4.11), ridges with rounded grains (Figure 4.13), irregularly arranged grains (Figure 4.12), smooth ridges (Figure 4.10), even on the same spine. Large spines bear 14 to 21 longitudinal ridges. Thorns, ridges and space between ridges finely striated and covered by small grains (Figure 4.27). A spongy coat is visible in well-preserved spines (Figure 4.15). Base usually smooth, though both cylindrical (Figure 4.13) and fusiform (Figure 4.27) spines may have a partially crenulate acetabulum rim. Crosssection of primary spines (Figure 4.24): diameter of medulla $=25-30 \%$ Ds, cortex moderately thick, central lumen narrow.

Remarks and comparison. The type material of $C$. margaritifera described by Meneghini (1862) from the Pliocene of Tuscany, consisted of a fusiform primary spine from Latti (Siena) and a large interambulacral plate from Chiusi (Arezzo). The current whereabouts of this material is unknown (G. Bebi, IGF and C. Nocchi, MSNP, personal commun., 2006). The plate figured by Meneghini (1862, plate 2 , figure 13$)$ shows a noticeable thickness (4.5 $\mathrm{mm}$ ), a scrobicular ring with 20 large tubercles and furrows. Two large plates (one of them illustrated in Figure 4.29-30) recently recovered from the Pliocene Argille Azzurre Formation, at Asciano and Chiusi (type locality), show similar features and are close to the ambital plates of the largest tests from Milazzo and Lazzaro. Two spines attributed to this species by Landi (1929; plate 1, figures 17-18) and other spines under study from Asciano and Chiusi, are consistent with the original description given by Meneghini (1862) and the spines from Capo Milazzo. Therefore, we concur with Checchia Rispoli (1916) in attributing the Milazzo material to C. margaritifera. On the basis of the well-preserved fossil material from Capo Milazzo the interpretation of this species given by Checchia Rispoli (1916) and Landi (1929) is herein accepted, with additional observations. The base of the spine is smooth in the holotype of C. margaritifera, as well as in a part of the spines from Capo Milazzo and from the type area. However, the almost complete tests from Capo Milazzo clearly show crenulation on the adapical tubercles; consequently also a part of the primary spines should bear similar features.

The close affinity of the specimens from Milazzo to the extant species Cidaris rugosa (Clark, $1907)$ and the compatibility of most features to the typical characters of Cidaris Leske, 1778 support the original attribution to this genus by Meneghini (1862). Though Fell (1966) stated that "primary tubercles are non-crenulate aborally or (exceptionally) sub-crenulate" in Cidaris, a conspicuous crenulation is commonly present in the uppermost tubercles of Cidaris nuda Mortensen (1903). Also C. rugosa and C. abyssicola (Agassiz, 1869) may bear crenulation (Mortensen 1928; Phelan, 1970). Even in C. cidaris (Linnaeus, 1758), the type species, the adapical plates are crenulated in juvenile (Mortensen, 1928) as well in adult specimens, as observed by the first author in the adapical part of some large extant specimens (with D up to 38-42 $\mathrm{mm}$ ) from southern Italy, Gallipoli (MG.1033.36, Figure 4.8-9) and Pantelleria Island. In contrast to Fell's statement, therefore, partial crenulation of adapical tubercles thus seems to be quite common in the genus Cidaris. Smith and Kroh (2011) record only cylindrical spines in Cidaris, nevertheless fusiform spines are commonly present in Recent $C$. rugosa, C. abyssicola and C. blakei (Agassiz, 1878).

Also Stylocidaris Mortensen, 1909 may have more-or-less developed crenulation on tubercles, but fusiform spines are unusual in its living species (Mortensen, 1928). In the examined fossils the inner tubercles are not much smaller than the marginal ones, and the pores zones are not weakly incised, as described by Smith and Kroh (2011) for Stylocidaris.

Stylocidaris ? polyacantha (Reuss, 1860), from the Badenian of Austria, differs from C. margaritifera by spines much more slender, not fusiform and bearing thorns free of granulation. In Stylocidaris ? schwabenaui (Laube, 1869) primary spines are more slender and never crenulate, Ds does not exceed $4 \mathrm{~mm}$ (Kroh, 2005).

Based on the interpretation of Plegiocidaris peroni (Cotteau, 1877) by Philippe (1998) and Kroh (2005), this species differs from C. margaritifera by its spines with rather long collar, short neck and strong crenulation present in all spines, with the exception of the most adoral ones. Besides, the plates of $P$. peroni are never as large and thick as those from Milazzo and Tuscany. 
Recent $C$. rugosa from the Western Atlantic is close to C. margaritifera, as for the similar shaft ornamentation of primary spines, the comparable plate features and the occurrence of both cylindrical and fusiform spines in a same specimen. $C$. rugosa differs by the rare occurrence of crenulation (Mortensen, 1928; Phelan, 1970) and the presence of a sole adapical plate in each interambulacral series bearing a still rudimentary tubercle. C. abyssicola Agassiz, 1869, from the Atlantic Ocean, differs from $C$. margaritifera by its smooth primary spines and the lack of spongy-coat.

A part of the spines reported from Capo Milazzo as Cidaris cidaris (Linnaeus, 1758) by Checchia Rispoli (1916), examined at MGUP, bear crenulation and should be assigned to $C$. margaritifera; the acetabulum rim of the remaining spines is smooth or heavily abraded, thus preventing their reliable classification.

Distribution. Late Piacenzian, Gelasian and Calabrian of Capo Milazzo. Plio-Pleistocene of Grangiara, Spadafora and San Martino, near Messina, southern Italy (Checchia Rispoli, 1916). It is wide spread also in the Plio-Pleistocene Argille Azzurre Formation of Emilia (Landi, 1929) and Tuscany (Meneghini, 1862) and in the Calabrian of south Italy, at Venetico Marina (Messina), Ponte Calderaro (Catanzaro) and Croce Valanidi (Reggio Calabria). At Lazzaro (Reggio Calabria) C. margaritifera is associated with Stirechinus scillae within the white coral facies (Vazzana, 1996). Colella and D'Alessandro (1988) recorded it in the Early Pleistocene of Monte Torre (Cosenza, south Italy), in a bathyal association with $C$. cidaris and Echinus acutus.

Family HISTOCIDARIDAE Lambert, 1900 Genus HISTOCIDARIS Mortensen, 1903

Type species. Porocidaris elegans Agassiz, 1879, by original designation.

\section{Histocidaris sicula Borghi, 1999}

Figure 5.1-3, 5.6-13, 5.16

V*1999 Histocidaris sicula Borghi, pp. 116-117, pl. 4, figs. $1-4$ and $8-11$; pl. 5 , fig. 3 .

The description of this species is mainly that of Borghi (1999) to which we add relevant details as derived from newly collected material.

Material. Holotype consisting of four large interambulacral plates still in connection (MG.1073; Figure 5.1) and three primary spines lacking tips (MG.1074), very late Piacenzian-Gelasian marls of Cala S. Antonio. Two test fragments, 13 isolated interambulacral plates and 25 primary spines (MG.1033.01-12 and 19-33, MG.1034.20-21,
MG.1035.01-09, MG.1076-77); seven secondary spines (MG.1034.21, MG.1075.01-04); two primary oral spines (MG.1032.12); from the very late Piacenzian-Gelasian marls of Cala S. Antonio, Punta Lazzi and Punta Mazza and the Calabrian grey marls of Punta Lazzi.

Comparative material. Forty spines and one interambulacral plate (labelled as Histocidaris rosaria) from the Argille Azzurre Formation of Emilia (MG.1034.02-03, MG.1035.45-48) and Tuscany (MG.1034.01, MG.1035.44, 49).

Description. Largest fragments point to complete coronas with $D$ up to $90-100 \mathrm{~mm}$.

Ambulacra. Narrow, marginal tubercles present on every second or third plate, inner ones smaller and present on every fifth to eight plate. Pores non-conjugate; interporal partition rather large.

Interambulacra. Plates much wider than high, only the first adapical plate in each column almost equidimensional (Figure 5.16). At the ambitus, plate width almost twice the height. Only the first adapical interambulacral plate bears a rudimentary tubercle (Figure 5.16). Primary tubercles prominent, perforate and strongly crenulate. Scrobicular area slightly sunken; rings low and confluent. Secondary tuberculation scarce, leaving wide, bare areas outside scrobicular ring (Figure 5.2, 5.16).

Spines. Primary spines straight, cylindrical, slightly tapering towards the tip (Figure 5.13). Tip hollow and obliquely truncate (Figure 5.6) or blunt. Shaft glassy and smooth (Figure 5.7); there may be fine longitudinal ridges (Figure 5.8), in this case the shaft surface between ridges is smooth, not furrowed. Length of the collar is 0.8-2.1 times Ds (Figure 5.7-8). A complete spine (Figure 5.13 ) is $128 \mathrm{~mm}$ long, with maximum Ds=3.7 mm. Cross-section (Figure 5.3): cortex thin, lamellae radiating from the central part, medulla not clearly separated. Oral primaries flattened, slightly bent, with strongly serrate edges; tip blunt and longitudinally striate (Figure 5.10-12). Scrobicular spines longitudinally striate, with rounded point. Marginal spines slender, with blunt tip.

Remarks and comparison. Poriocidaris Mortensen, 1909 differs from Histocidaris by its bivalved pedicellariae and longer collar (Mortensen, 1928). Clark (1907) and Smith and Kroh (2011) proposed their synonymy. The length of the collar in the 


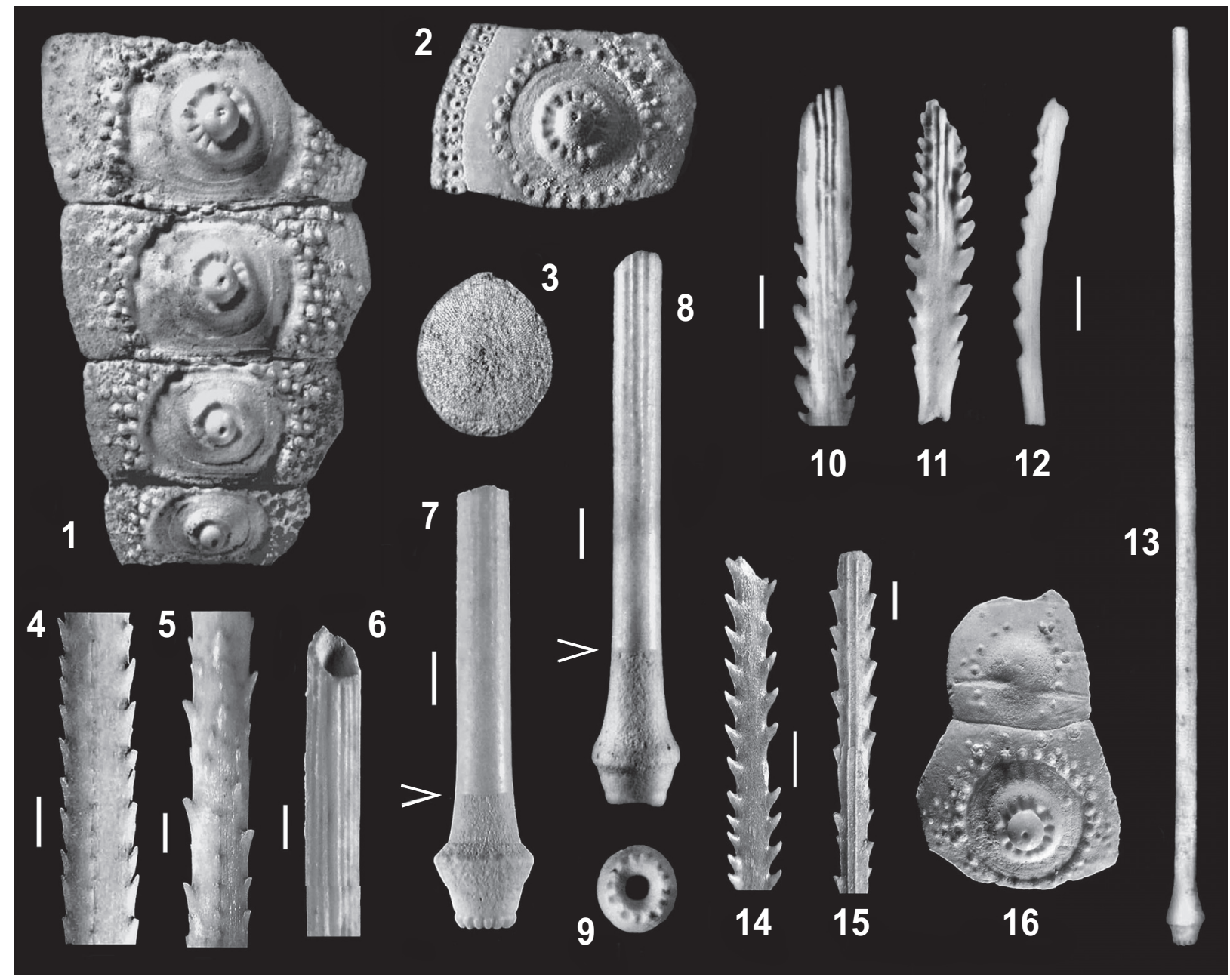

FIGURE 5. Plio-Pleistocene species of the genus Histocidaris Mortensen, 1903 from Capo Milazzo (5.1-3, 5.6-13, 5.16) and from Italy mainland (5.4-5, 5.14-15). Histocidaris sicula Borghi, 1999; uppermost Piacenzian-Gelasian of Cala S. Antonio. 5.1, holotype (MG.1073), W=27 mm; 5.2, interambulacral plate with the adjoining ambulacral plates, (MG.1033.42), W=12 mm; 5.3, cross section of a primary spine (MG.1033.06), Ds=2.6 mm; 5.6, close up view of the hollow tip of a primary spine (MG.1033.33), Ds=2.7 mm; 5.7, primary spine (MG.1035.08) with smooth shaft, the arrow marks the edge of the collar, $2 \mathrm{~mm}$ long, Ds=2.5 mm; 5.8, primary spine (MG.1074) with low ridges and crenulate acetabulum rim (5.9), the arrow marks the edge of the collar, which is $5.8 \mathrm{~mm}$ long, Ds=2.8 mm; 5.10, adoral primary spine (MG.1033.09), L=12 mm; 5.11, adoral primary spine (MG.1077), L=11 mm, with lateral view (5.12); 5.13, complete primary spine (MG.1035.01), L=128 mm; 5.16, adapical interambulacral plates (MG.1033.32), W=22 mm. Histocidaris rosaria (Bronn, 1831). 5.4, primary spine with sharp spinules (MG.1034.02), Ds=3 mm, Piacenzian, Campore quarry, Salsomaggiore (Parma); 5.5, primary spine with prominent thorns (MG.1034.03), Ds=4 mm, Piacenzian, Campore quarry, Salsomaggiore; 5.14, thorny adoral primary spine (MG.1034.04), L=14 mm, Piacenzian, Campore quarry, Salsomaggiore; 5.15, tip of a primary spine, Ds=2.5 mm (MG.1034.01), early Pliocene, Vescona quarry, Asciano (Siena). Scale bars equal $2 \mathrm{~mm}$.

spines from Milazzo is in favour of the attribution to Histocidaris.

H. magnifica Mortensen, 1928 from the Pacific Ocean shows a similar ornamentation, but its spines are curved, and the ambulacral tubercles are more numerous and differently arranged. Primary spines of the western Atlantic $H$. sharreri (Agassiz, 1880) are similar but often bear well- developed thorns. The interambulacral plates of $H$. sharreri are not as broad as those of $H$. sicula, marginal tubercles series are more regularly arranged and the inner tubercles are more numerous. H. rosaria (Bronn, 1831), from the Plio-Pleistocene Argille Azzurre Formation, differs by primary spines bearing longer collar (up to 3-4 times Ds), blunt tip (Figure 5.15), sharp and promi- 
nent thorns or serrate ridges (Figure 5.4-5). It differs also by less wide interambulacral plates and narrower extra scrobicular areas packed with secondary tuberculation.

Distribution. Late Piacenzian-Gelasian of Capo Milazzo, where it is present, though rather rare; also in the Calabrian of Punta Lazzi.

Family ECHINIDAE Gray, 1825

Genus STIRECHINUS Desor, 1856

Type species. Stirechinus scillae Desor, 1856, by monotypy.

Stirechinus scillae Desor, 1856

Figure 6.1-12

? 1747 Echinus e Messana Scilla, pl. 13, fig. 1; pl. 26, fig. B.

? 1853 Tripneustes sardicus Agass. e Desor; Aradas, p. 178.

* 1856 Styrechinus scillae Desor, p. 131, pl. 17 bis, figs. 6, 7-7a.

v. 1916 Styrechinus scillae Desor; Checchia Rispoli, pp. 235-236, pl. 26, figs. 42-50; pl. 27, figs. 6-7.

Material. Seven complete or almost complete coronas (MG.1034.15-18, MG.1035.20-22), two of them still bearing the apical disc. Eleven test fragments (MG.1034.19; MG.1035.19 and 23), a test fragment with primary spines (MG.1086.1-2), from the very late Piacenzian-Calabrian of Capo Milazzo. Eight complete or almost complete tests (MG.1034.1011; six of them in the Checchia Rispoli's collection, at MGUP with no catalogue number), from the Early Pleistocene of Messina (NE Sicily). Two test fragments (MG.1034.12) from the Calabrian of Lazzaro (Calabria).

Description. Test more or less elevated, hemispherical, seldom sub-conical. Maximum test $D=61$ $\mathrm{mm}$ (Table 3). Checchia Rispoli recorded D size up to $64 \mathrm{~mm}$.

Apical disc. Dicyclic with exert ocular plates (Figure 6.12). Also a juvenile specimen (MG.1035.22) shows a similar structure.

Ambulacra. Ambulacral plates with P2 isopores (sensu Smith, 1978) surrounded by rather narrow muscle attachment area, the interporal partition is arched. Pore-pairs narrow. On each plate, a prominent, imperforate and uncrenulated single primary tubercle.

Interambulacra. A single primary tubercle, somewhere scrobiculate (Figure 6.8), on each plate. Primary tubercle series usually regular, but a few ambulacral and interambu- lacral plates may bear tubercles much smaller than the others (Figure 6.2). Primary tubercles, both in ambulacra and interambulacra, linked into vertical columns by pronounced ridges, from the ambitus aborally (Figure 6.4). Ridges present also in juvenile specimens (Figure 6.910 ), sometimes they are lacking (Figure 6.8). Small secondary tubercles widely scattered, leaving the interradius largely naked. Sutures deeply incised.

Peristome. The diameter of the peristome ranges from a mean of $48 \% \mathrm{D}$ in young specimens $(D=4-8 \mathrm{~mm})$ to $37 \% \mathrm{D}$ in the adults $(D=33-$ $61 \mathrm{~mm}$ ). Buccal notches indistinct. Auricles well developed, high.

Spines. A middle-sized test (MG.1086; $D=44 \mathrm{~mm}$ ) from Punta Lazzi retains spines; these are slender, longitudinally striated, with smooth base, rather prominent and crenulate ring and sharp point (Figure 6.6-7). Length up to $20 \mathrm{~mm}$.

Remarks. The spines of this species are not short and stout, as described by Checchia Rispoli (1916). Very likely the maximum length of $5 \mathrm{~mm}$, as reported by this author, is referred to a specimen retaining only the shortest spines.

Distribution. Late Piacenzian-Gelasian of Punta Lazzi. Less frequent at Cala S. Antonio, Punta Mazza and in the Calabrian of Punta Lazzi. Surroundings of Messina (Desor, 1856; Checchia Rispoli, 1916): three specimens under study were recovered at Contrada Petrazza and Coilare near Messina, from sediments dated to the Calabrian (Micali and Villari, 1989). Calabrian of Lazzaro (Reggio Calabria), associated to C. margaritifera. It is recorded also from the late Miocene, but Wright's (1864) citation from the upper Coralline Limestone Formation of Malta is dubious, since no other author dealing with the Maltese echinoids recorded it again. Also the citation from the Tortonian of Capo San Marco, Sardinia (Mariani and Parona, 1887) needs confirmation.

\section{THE ASSEMBLAGE AND ITS RELATIONSHIP TO OTHER ARGILLE AZZURRE FM. FAUNAS}

Fragments of Echinus acutus (Lamarck, 1816) were collected in the late Pliocene-Early Pleistocene of Cala S. Antonio and Punta Lazzi (MG.1035.34-43). Plates up to $26 \mathrm{~mm}$ indicate large-sized tests, with very small primary tubercles. The plate-surface may be smooth or covered by granules as in Recent specimens. Almost complete 


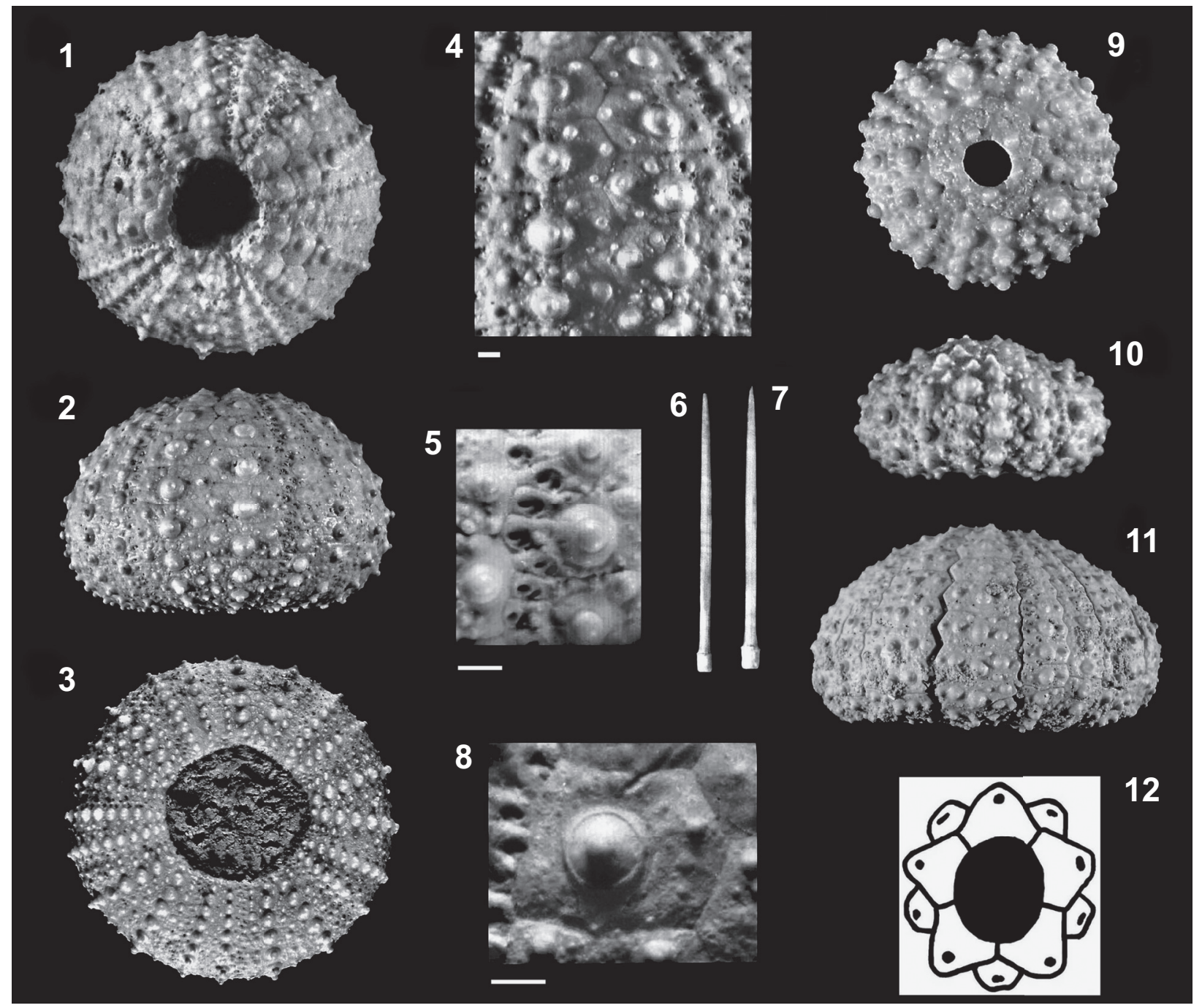

FIGURE 6. Stirechinus scillae Desor, 1856 from the Plio-Pleistocene of Sicily. 6.1-3, complete test (MG.1034.10), $\mathrm{D}=33.5 \mathrm{~mm}$, Early Pleistocene of Contrada Coilare (Messina), showing apical (6.1), lateral (6.2) and oral (6.3) views. 6.4, close up of the ridges linking the primary tubercles (MG.1034.18); 6.5, close up view of a pore-zone (MG.1034.19); 6.6-7, primary spines, L=20 mm (MG.1086.01-02); 6.8, close up view of an interambulacral scrobiculate primary tubercle, lacking ridges. All from the very late Piacenzian-Gelasian of Punta Lazzi. 6.9-10, apical (6.9) and lateral (6.10) views of a complete juvenile test (MG.1035.22), D=6.4 mm, very late Piacenzian-Gelasian of Punta Mazza; 6.11, lateral view of a complete corona, $D=54 \mathrm{~mm}$ (MG.1034.18), very late Piacenzian-Gelasian of Punta Lazzi; 6.12, scheme of the apical system taken from a specimen of the Checchia Rispoli collection (MGUP); figured in Checchia Rispoli, 1916, plate 27, figure 6. Scale bars equal $2 \mathrm{~mm}$.

tests of $E$. acutus were described from coeval deposits cropping out in the surroundings of Messina (Checchia Rispoli, 1916; Gaetani and Saccà, 1984), associated to Stirechinus scillae and Spatangus purpureus (Müller, 1776).

Incomplete specimens of Spatangus purpureus were collected also at Capo Milazzo associated to other spatangoids (MG.1033.13-18), whose identification is not reliable due to poor preservation.
The composition of the echinoid assemblage of the Tyrrhenian sediments at Capo Milazzo is quite different. It consists of fragments and whole tests belonging to shallow water species still living in the Mediterranean Sea: Paracentrotus lividus (Lamarck, 1816) (MG.1033.35), Genocidaris maculata Agassiz, 1869 (MG.1033.37) and Echinocyamus pusillus (Müller, 1776) (MG.1035.10).

There is a number of shared species between the echinoid assemblages of Capo Milazzo and those of the Argille Azzurre: Cidaris cidaris, C. mar- 
TABLE 3. Stirechinus scillae, Desor, 1856: measurements of the examined complete specimens.

\begin{tabular}{|c|c|c|c|c|c|c|c|}
\hline Inventory Code & D & $\mathbf{H}$ & $\mathrm{Da}$ & Dp & nA & nIA & Locality \\
\hline MG.1034.18 (Figure 6.4, 6.11) & 61.0 & 38.4 & - & 22.6 & - & - & Salice (Messina) \\
\hline MG.1034.11 & 57.1 & 36.5 & 10.8 & - & - & - & Contrada Coilare (Messina) \\
\hline MG.1034.19 (Figure 6.5) & 54.0 & 31.2 & 10.4 & - & $22-23$ & $15-16$ & Punta Lazzi \\
\hline MG.1034.10 (Figure 6.1-3) & 33.5 & 20.4 & 9.2 & 12.7 & $18-19$ & $12-13$ & Contrada Coilare (Messina) \\
\hline MG.1034.15 & 14.5 & 9.1 & 3.9 & - & - & - & Punta Lazzi \\
\hline MG.1034.17 & 8.3 & 4.6 & - & 3.7 & - & - & Punta Lazzi \\
\hline MG1035.22 (Figure 6.9-10) & 6.4 & 3.5 & 2.6 & 3.2 & $7-8$ & 7 & Punta Mazza \\
\hline MG1035.20 & 4.2 & 2.0 & 2.3 & 2.3 & 6 & $5-6$ & Punta Mazza \\
\hline
\end{tabular}

garitifera, C. cerullii, Echinus acutus and Spatangus purpureus. However, most of these species have often been recorded also from shallow water deposits, and the same is true for Brissopsis lyrifera Forbes, 1841 and Brissopsis atlantica Mortensen, 1913, which are frequent in the Argille Azzurre beds but lacking at Capo Milazzo. Cidaris margaritifera looks like the only strictly bathyal echinoid occurring in both areas. This species, firstly described from Tuscany (Meneghini, 1862), is present also in several Plio-Pleistocene localities of Emilia-Romagna (Vinassa de Regny, 1897; Landi, 1929). Indeed, Stirechinus scillae was never cited from the Argille Azzurre, nor was Histocidaris sicula.

Although the poor preservation of the spatangoids from Milazzo and the surroundings of Messina prevent their reliable identification, some fragments resemble better preserved specimens from the Piacenzian bathyal clays of Piedmont and Liguria attributed to Schizaster braidensis Botto
Micca, 1896, Hemiaster ovatus (Sismonda, 1842) and Hemiaster sp. (Cavallo et al., 1986). Similar specimens are present also in the Argille Azzurre of Emilia-Romagna, e.g., at Campore, near Salsomaggiore (Parma), Quattro Castella and San Ruffino (Reggio Emilia; Figure 7.3). These echinoids are always associated with a deep-water fauna and, since they often retain spines and even valves of pedicellariae, they are assumed to belong to the autochthonous bathyal assemblage.

Schizaster braidensis is well characterized by its small size (maximum observed test length $=46$ $\mathrm{mm}$ ), very short and almost roundish posterior petals and anterior margin only slightly indented by the narrow and flush unpaired anterior ambulacrum (Figure 7.1). On the base of the specimens reported by Airaghi (1901, plate 23, figure 5) as Hemiaster ovatus from northern Italy (Zinola and Bra), and those from the Argille Azzurre Formation (Figure 7.3), Schizaster ovatus Sismonda, 1842 should be regarded as belonging to the genus

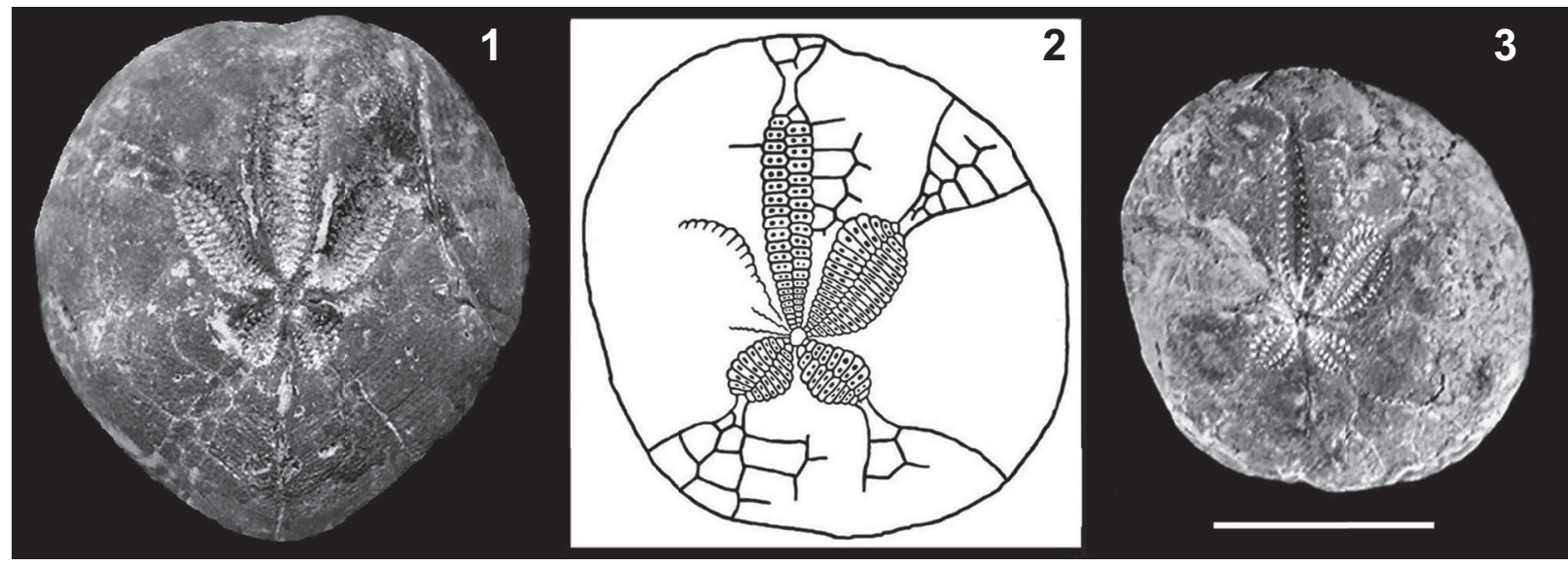

FIGURE 7. Spatangoid species from the Pliocene of north Italy. 7.1, aboral view of Schizaster braidensis Botto Micca, 1896, L=29 mm (Dip.Te.Ris IV.G60), Zanclean-Piacenzian of Genova. 7.2-3, aboral view of Holanthus ovatus (Sismonda, 1842), Pliocene of San Ruffino (Reggio Emilia), with the enlarged scheme of the plating structure (7.2) from a compete test, L=21 mm, MG.1034.06 (7.3). Scale bar equals $1 \mathrm{~cm}$. 
TABLE 4. Echinoid species recorded at Capo Milazzo.

\begin{tabular}{|c|c|c|c|c|c|c|c|c|c|c|c|c|}
\hline \multirow[b]{2}{*}{ Species } & \multicolumn{3}{|c|}{ Punta Lazzi } & \multicolumn{3}{|c|}{ Cala S. Antonio } & \multicolumn{3}{|c|}{ Light house } & \multicolumn{3}{|c|}{ Punta Mazza } \\
\hline & 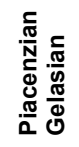 & $\begin{array}{l}\frac{5}{\frac{\pi}{2}} \\
\frac{0}{\frac{\pi}{\pi}} \\
0 \\
0\end{array}$ & 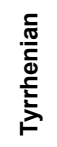 & 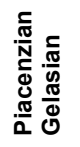 & $\begin{array}{l}\frac{5}{\pi} \\
\frac{0}{\frac{0}{\pi}} \\
\frac{\pi}{\pi}\end{array}$ & 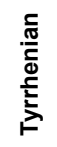 & 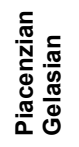 & $\begin{array}{l}\frac{5}{\frac{\pi}{2}} \\
\frac{0}{\frac{\pi}{\pi}} \\
0 \\
0\end{array}$ & 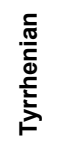 & 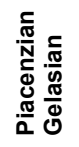 & $\begin{array}{l}\frac{\pi}{\frac{\pi}{6}} \\
\frac{0}{\pi} \\
\frac{\pi}{\pi}\end{array}$ & 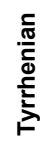 \\
\hline Cidaris cerullii (Checchia Rispoli, 1923) & $x$ & & & & & & & & & & & \\
\hline Cidaris cidaris (Linnaeus, 1758) & $x$ & & & $x$ & & & & & & & & \\
\hline Cidaris margaritifera Meneghini, 1862 & $x$ & $x$ & & $x$ & & & $x$ & & & $x$ & $x$ & \\
\hline Histocidaris sicula Borghi, 1999 & $x$ & $x$ & & $x$ & & & $x$ & & & $x$ & & \\
\hline Echinus acutus Lamarck, 1816 & $x$ & & & $x$ & & & & & & & & \\
\hline Stirechinus scillae Desor, 1856 & $x$ & $x$ & & $x$ & & & & & & $x$ & & \\
\hline Spatangus purpureus (Müller, 1776) & $x$ & & & $x$ & & & & & & $x$ & & \\
\hline Paracentrotus lividus (Lamarck, 1816) & & & & & & $x$ & & & & & & \\
\hline Genocidaris maculata Agassiz, 1869 & & & & & & $x$ & & & & & & \\
\hline Echinocyamus pusillus (Müller, 1776) & & & & & & $x$ & & & & & & \\
\hline
\end{tabular}

Holanthus Lambert and Thiery, 1924. In fact those specimens show a narrow frontal ambulacrum, broad petals and a marked narrowing in the ambulacra immediately beneath the petals (compare Figure 7.2 and Cavallo et al., 1996, figure 424), which are typical features of Holanthus. The Pliocene $H$. ovatus is closely related to $H$. expergitus (Lovén, 1874), the sole species of this genus today living in the Atlantic-Mediterranean area. In particular, the plating structure of the Pliocene specimens corresponds to that of $H$. expergitus as reported by Smith and Kroh (2011). Maybe these two species are synonymous but, since the holotype of $H$. ovatus was lost (D. Ormezzano, MSNT, personal commun., 2010), further investigation is needed to clear the question.

\section{DISCUSSION}

\section{Palaeoecological Notes and Relationships with Western Atlantic Assemblages}

The Plio-Pleistocene echinoid fauna of Capo Milazzo (Table 4) has a low diversity, being largely dominated by three species: Cidaris margaritifera, Histocidaris sicula and Stirechinus scillae. Shallowwater echinoids are lacking, except in the Tyrrhenian beds.

Some complete tests preserve spines and jaws. In this case echinoids were likely quickly buried in their life position. The specimens with plates still in connection are fragile and certainly do not represent a reworked fauna. Since test fragments are commonly separated along the sutures, most of the echinoids fell apart in situ after death (Smith,
1984) and spines and plates were subsequently moderately displaced by bottom currents, very likely within the original biotope. The occurrence of a moderate bottom current was suggested by Gaetani and Saccà (1984) to explain the concentration of brachiopod shells. Cidaroid skeletons are expected to break apart after a few days of decay, under normal conditions (Greenstein, 1992). Shäfer's (1972) experiments proved that coronas of Echinus Linnaeus, 1758 disintegrated within two weeks in quiet water and in less time if disturbed by benthic scavengers. However, rapid disintegration is contradicted by the common occurrence of postmortem epibionts encrusting articulated specimens at Capo Milazzo. Kidwell and Baumiller (1990) and Nebelsick et al. (1997) showed that low water temperatures retard the disarticulation process and preserve complete coronas for several months, even for years, in the absence of agitation. These taphonomic observations point to a cold-water and low-energy environment. The regular echinoids of Capo Milazzo bear partitioned isopores, with poor development of the muscle attachment area around the pores: this feature is assumed as typical of deep and soft bottoms (Smith, 1978). The large and flat adoral surface of Stirechinus, bearing numerous rather short primary spines, is well suited for life on muddy bottoms (Smith, 1978). The test and spine features of this echinoid are consistent with those of Echinus acutus, which is common at $100-400 \mathrm{~m}$ depth in the present Mediterranean muddy substrates (Tortonese, 1977). 
The bathymetric range of the Recent Cidaris rugosa and Stirechinus tyloides, close relatives to Cidaris margaritifera and Stirechinus scillae, are 130-540 m (Phelan, 1970) and 350-760 m depth (Mortensen, 1943), respectively; at those depths the temperature of the present western North Atlantic ranges from a minimum of $7^{\circ} \mathrm{C}$ (Emery, 2003) to a maximum of about 19 to $20^{\circ} \mathrm{C}$ (Fuglister, 1954).

Cidaris rugosa and Stirechinus tyloides, mainly feed on dead globigerinoids (Mortensen, 1928, 1943). Planktonic foraminifers, abundant within the bioclastic marls of Capo Milazzo (Violanti, 1988), likely provided the echinoids with their main source of food.

Palaeoecological data based on the observation of the echinoid-assemblage are consistent with the interpretation of the depositional environment reported in the recent literature dealing with the Plio-Pleistocene of Capo Milazzo. The autochthony of the fauna was suggested by Gaetani and Saccà (1984) and Fois (1990a, 1990b). Likewise, there is no evidence for displacement/reworking of the molluscan assemblages (A. Villari, personal commun., 2008). All of the species reported from Capo Milazzo, which are still extant in the Atlantic, are known to inhabit the upper bathyal zone. The same interpretation was derived from investigations of the brachiopods (Gaetani and Saccà, 1984), molluscs (Palazzi and Villari, 1996) and corals (Vertino, 2004). In particular, Madrepora oculata Linnaeus, 1758 and Lophelia pertusa (Linnaeus, 1758), two corals which are common at Capo Milazzo (Gaetani and Saccà, 1984), are considered as typical of bathyal environments, or at least of the circalittoralbathyal transition (Vertino, 2004). Today their bathymetric range is $300-1000 \mathrm{~m}$ on Mediterranean hard substrates (Riedl, 1991). Studies carried out on populations of Lophelia pertusa in the Gulf of Mexico (CSA International, Inc., 2007) indicate that the upper thermal threshold for long-term survival of these corals lies between $10^{\circ} \mathrm{C}$ and $15^{\circ} \mathrm{C}$, and there is no mortality observed at the lowest experimental temperature of $5{ }^{\circ} \mathrm{C}$. The sites studied ranged in depth from $310 \mathrm{~m}$ to $650 \mathrm{~m}$, with the shallowest site representing the upper temperature threshold for Lophelia. An upper temperature threshold of $12{ }^{\circ} \mathrm{C}$ has been suggested also for other geographical locations (Freiwald, 1998; Rogers, 1999). Deep-sea species dominate also the ostracod assemblages and a typical psychrospheric species was recognised in all the samples from Capo Milazzo examined by Sciuto (2003). Shallow-water forms and evidence of algal activity are lacking (Gaetani and Saccà, 1984). These observations are in accord with the attribution of the studied echinoid assemblages from Milazzo to the shallower horizons of the bathyal zone, probably slightly deeper than $300 \mathrm{~m}$, characterized by oceanic environmental conditions. In particular the occurrence of species such as Histocidaris sicula, H. rosaria, Cidaris margaritifera, Stirechinus scillae and Schizaster braidensis indicate this palaeoenvironmental setting.

Gaetani and Saccà (1984) recognised two different palaeocommunities at Capo Milazzo: the Recent Mediterranean white corals biocoenosis ("Coraux Blancs" of Pérès and Picard, 1964), on the hard substrates and in the thin vertical cracks within the metamorphic basement, and the bathyal muddy bottom biocoenosis ("Vases Bathyales" of Pérès and Picard, 1964), within the coarse marly facies. They suggested that some of the brachiopods belonged to the former biocoenosis and were living on hard substrata adjacent to depressions filled with marly sediments. As for the echinoids, Cidaris rugosa and Stirechinus tyloides may live on both hard and soft substrates and the occurrence of their Pliocene relatives in the marly/mudstone sediments at Milazzo is consistent with their way of life. The same is for species of Histocidaris, whose Recent representatives live on muddy substrates.

Records of strictly bathyal echinoid assemblages are generally scanty, with particular regard to the Mediterranean area: bathyal spatangoids have been described from the Serravallian Pakhna Formation of Cyprus (Smith and Gale, 2009) and the Langhian Pantano Formation of northern Italy (Borghi, 2012), and correspondence drawn with the Recent echinofauna of the Caribbean zone. The scarcity of information on these assemblages, with particular regard to the regular echinoids, underlines the importance of the Plio-Pleistocene assemblage of Milazzo, which comes from a key time in the evolution of the Mediterranean.

The taxonomic data set provided for the echinoids from Capo Milazzo and the other examined localities points to interesting affinities between the Mediterranean and the western Atlantic echinoid assemblages. Cidaris margaritifera is morphologically close to C. rugosa (Clark, 1907), today living on soft bottoms of the western Atlantic Ocean, suggesting that these species may be closely related (compare Phelan, 1970). By its spine shape Histocidaris sicula resembles $H$. sharreri, which lives in the West Indies, from the Leeward Islands, to Nevis and St. Kitts, at a depth of 200-740 m (Serafy, 1979). Stirechinus tyloides (Clark, 1912), the 
only living species attributed to this genus (Smith and Kroh, 2011), is confined to the western Atlantic coast from Georgia to Florida (Mortensen, 1943). The spines of Histocidaris rosaria from the Argille Azzurre Formation are close to those of $H$. nuttingi Mortensen, 1928, distributed from Cuba to Antigua (225-740 m; Donovan et al., 2005). Holanthus ovatus is closely related to $H$. expergitus, the sole species of this genus living in the Atlantic Ocean and the Mediterranean Sea today.

Unfortunately, the fossil record of the Pliocene Caribbean deep-water echinoids is very scarce (Donovan and Paul, 1998), thus preventing comparison with the Capo Milazzo fauna. Although echinoids have been recorded from deep-water settings of Miocene age in the Caribbean (Donovan et al., 2005), these are almost exclusively composed of allochthonous material transported downslope from shallow-water settings (Smith and Gale, 2009). However, in the early Miocene Montpelier Formation of Jamaica, Histocidaris sp., likely truly autochthonous to this setting, is represented by isolated thorny spines (compare Donovan et. al, 2005: plate 5, figures 8-9), which are close to those of $H$. rosaria from the Argille Azzurre Formation of Italy. Besides, spines from the same locality attributed to Prionocidaris ? sp. (Donovan et al., 2005, plate 1, figures 9-10, 12-13) resemble those of Cidaris margaritifera and C. rugosa.

Today, only 12 species of echinoids are known to inhabit the deep waters of the Mediterranean (below 250-300 m depth; Table 2); all of them are present also in the eastern Atlantic Ocean, whereas only five ( $42 \%$ of the deep-water Mediterranean stock) live also in the western Atlantic. The present Mediterranean echinoid assemblage has close affinities with the north-eastern Atlantic. In contrast to the modern deep-water Mediterranean fauna, a strong link between western Atlantic (the Caribbean zone in particular) and Mediterranean bathyal echinoids existed during the middle Miocene and the Plio-Pleistocene, at least until the Calabrian.

\section{Evidence for the Psychrosphere}

The modern deep-sea fauna of the Mediterranean is relatively young, having arisen through gradual colonisation since the Pliocene by immigration from the Atlantic deep sea through the Strait of Gibraltar. In particular, the Mediterranean bathyal biocoenoses are similar to those in the northeastern Atlantic, but comparatively impoverished in regard to diversity and abundance
(Bouchet and Taviani, 1992; Taviani, 2002; La Perna, 2003).

The Mediterranean deepest fauna (e.g., molluscs, brachiopods, corals) generally has a wider bathymetric distribution elsewhere. Furthermore, the Mediterranean strictly deep-water species are rare and the percentage of deep-water endemic species is low and decreases with depth (Emig and Geistdoerfer, 2004). These traits fit well with the present Mediterranean echinoid fauna: all the 12 species occurring below 250-300 m depth are widespread in the Atlantic Ocean (Table 2), and eight of them (67\%) inhabit also the north-eastern Atlantic thus showing a temperate to boreal affinity. A sole echinoid, Holanthus expergitus, is confined to bathyal depths, deeper than $400 \mathrm{~m}$, in the Mediterranean, as well as in the Atlantic. No endemic deep-water echinoid is known from the present-day Mediterranean.

The Mediterranean today displays homothermy: the water temperature remains constant and high at depths below $200-300 \mathrm{~m}\left(13-13.5^{\circ} \mathrm{C}\right.$ in the west and $14-15^{\circ} \mathrm{C}$ in the east). The deep water is very saline with values up to $38.5-39 \mathrm{psu}$. These conditions create a strongly stratified water body, which further enhances the oligotrophy of the Mediterranean (Emig and Geistdoerfer, 2004). Almost all the living Mediterranean deep species are also found in shelf settings (Table 1). Thus they are eurybathic species and, since most of them are found today also in the cold deep water of the Atlantic, they are also eurythermal. Also $H$. expergitus is eurythermal, since it is able to adapt to the relatively high temperatures occurring in the deep Mediterranean and to the cold Atlantic deep waters: at $3120 \mathrm{~m}$ depth, the deepest record for this species (Tortonese, 1977), the temperature of the NADW (North Atlantic Deep Water; see Emery, 2003 ) is less than $4^{\circ} \mathrm{C}$. The rarity of this species in the Mediterranean is likely due to the severe conditions of its deep environments (warmer and with higher salinity degrees than in the Atlantic).

Of the fossil echinoid species discussed here, the eurythermal-eurybathic Cidaris cidaris, Echinus acutus and Spatangus purpureus do not indicate deep-water conditions, whereas the strictly bathyal Histocidaris sicula, H. rosaria, Cidaris margaritifera, Stirechinus scillae and Schizaster braidensis indicate that a discrete community of echinoids was particularly adapted to Mediterranean soft bottoms with oceanic psychrospheric settings during the Plio-Pleistocene. Like other deep faunal assemblages, these species did not survive the 
TABLE 5. Strictly bathyal echinoids inhabiting muddy bottoms of the present Eastern Atlantic (Kohler, 1927; Mortensen, 1928).

\begin{tabular}{lcl}
\hline \multicolumn{1}{c}{ Species } & Depth range (m) & Distribution in the eastern Atlantic \\
\hline Trigonocidaris albida Agassiz, 1869 & $570-700$ & Bay of Biscay, Madeira and Azores Islands \\
Poriocidaris purpurata (Thomson, 1872) & $750-1800$ & from Iceland to Canary Islands \\
Phormosoma placenta Thomson, 1872 & $275-2500$ & from Iceland to the Gulf of Guinea \\
Calveriosoma hystrix (Thomson, 1872) & $360-1525$ & from Iceland to Canary and Azores Islands \\
Araeosoma fenestratum (Thomson, 1872) & $145-900$ & from Denmark to Portugal \\
Hygrosoma petersii (Agassiz, 1880) & $730-2870$ & Gulf of Biscay to Azores Is., North African coasts \\
\hline
\end{tabular}

late Quaternary loss of the psychrosphere in the Mediterranean.

It seems likely that strictly deep-water species disappeared in the Mediterranean also during the warmest climatic interglacial periods. Surviving Atlantic populations probably acted as sources for restocking them, at least till the late Early Pleistocene. Since no significant changes in the composition of the Mediterranean bathyal echinoid assemblage from the early Pliocene to the Early Pleistocene (Calabrian) are seen in the fossil record, the composition of the Atlantic deep-water benthos did apparently not change during that time.

The deep-water echinoids occurring in the eastern Atlantic close to Gibraltar today (Table 5) have never been recorded from the Mediterranean. The Mediterranean outflow and the high elevation of the Gibraltar Sill represent major obstacles for immigration into the Mediterranean today. In addition, the present homothermal conditions, the high salinity and low food availability further hamper successful settling.

\section{CONCLUDING REMARKS}

Seven echinoid species were recognized within the bathyal deposits at Capo Milazzo, providing a rare opportunity of studying an autochthonous late Pliocene-Early Pleistocene deep-water echinoid fauna of the Mediterranean. The studied assemblages are characterised by low diversity, being largely dominated by Cidaris margaritifera, Stirechinus scillae (also known from other parts of the Mediterranean) and Histocidaris sicula, which seems endemic. Only three additional well-defined strictly bathyal echinoids are known from the PlioPleistocene Argille Azzurre Formation of the Mediterranean: Histocidaris rosaria (Bronn, 1831), Schizaster braidensis Botto Micca, 1896 and Holanthus ovatus (Sismonda, 1842).

Similarly to the Miocene deep-water spatangoid fauna of the Mediterranean, these bathyal regular-echinoid assemblages show strong affinities with the western Atlantic, the Caribbean area in particular. This suggests that during the late Cenozoic, at least until the Calabrian, the deepwater Mediterranean-Atlantic faunal exchange within echinoids was different from the Recent setting that is characterized by a strong link to the eastern Atlantic.

Within the studied assemblages, several echinoid species from the Mediterranean late Cenozoic are well adapted to an upper bathyal muddy seafloor, rich in bioclastic detritus, characterized by cold waters and psychrospheric conditions. Other species, including species still living in the presentday Mediterranean, survived the loss of the psychrosphere thanks to their eurybathic/eurythermal nature. The strictly bathyal species found at Capo Milazzo vanished from the Mediterranean during the late early Quaternary due to the loss of the psychrosphere. They possibly suffered periodic extinctions during the Pleistocene interglacials and had the opportunity of re-immigrating from surviving Atlantic populations during cold periods. The elevation of the Gibraltar sill and the unfavourable current regime in that area seems to prevent the entrance of the modern bathyal taxa from the eastern Atlantic into the Mediterranean. The presence of Holanthus expergitus, the sole strictly bathyal echinoid occurring in the Mediterranean today, indicates that only eurythermal species are able to settle the Mediterranean deep waters, which are characterized by homothermy, displaying high and constant water temperature at depths below 200$300 \mathrm{~m}$. However, other environmental conditions, such as high salinity and food scarcity at depth, are further factors actually preventing the settlement of deep-water echinoids in the Mediterranean Sea.

\section{ACKNOWLEDGEMENTS}

The authors are grateful to L. Bertolaso (Reggio Emilia), S. Palazzi (Modena), G. Vecchi (Reggio Emilia) and A. Villari (Messina) who provided 
information and fossil material from Milazzo and Tuscany. Thanks also to M.C. Bonci (Dip.Te.Ris.), R. Manni (MPUR), P. Monegatti (IGUP), D. Ormezzano (MSNT) and P. Serventi (IPUM) who allowed access to the collections housed at their Institutes. G. Bebi (IGF) and C. Nocchi (MSNP) provided information about the location of the fossil material studied by Meneghini. Special thanks in memory of V. Burgio who allowed access to the Checchia Rispoli collection at MGUP. A draft of this article benefited from the helpful and constructive comments by $\mathrm{A}$. Kroh (NHMW). The authors are grateful to the reviewers and the editors for the detailed corrections to the manuscript. The Spanish and French translations of the plain language summary were respectively provided by Diego A. GarcíaRamos (Wien) and Maria Luisa Runfola (Palermo).

\section{REFERENCES}

Agassiz, A. 1869. Preliminary Report on the Echini and Starfishes dredged in deep water between Cuba and the Florida Reefs, by L. F. de Pourtalès. Bulletin of the Museum of Comparative Zoology at Harvard College, 1:253-308.

Agassiz, A. 1878. Report on the results of dredging, under the supervision of Alexander Agassiz, in the Gulf of Mexico, by the U.S. Coast Survey Steamer "Blake". Report on the Echini. Bulletin of the Museum of Comparative Zoology at Harvard College, 5:181195.

Agassiz, A. 1879. Preliminary report on the Echini of the exploring expedition H.M.S. Challanger. Proceedings of the American Academy of Arts and Science, 14:182-261.

Agassiz, A. 1880. Preliminary report on the echini. Reports on the results of dredging, under the supervision of Alexander Agassiz, in the Caribbean Sea in 1878-1879, and along the Atlantic Coast of the United States during the summer of 1880 , by the U.S. Coast Survey Steamer "Blake". IX. Bulletin of the Museum of Comparative Zoology at Harvard College, 8:69-84.

Airaghi, C. 1901. Echinidi terziari del Piemonte e della Liguria. Palaeontographia Italica, 7:22-126.

Antonioli, F., Kershaw, S., Renda, P., Rust, D., Belluomini, G., Ceratoli, M., Radtke, U., and Silenzi, S. 2006. Elevation of the last interglacial highstand in Sicily (Italy): a benchmark of coastal tectonics. Quaternary International, 145-146:3-18.

Aradas, A. 1853. Monografia degli echinidi viventi e fossili della Sicilia. Parte quarta. Famiglia di Cidariti Atti dell'Accademia Gioenia di Scienze Naturali, serie seconda, 8:151-178.
Arisco, G., Arnone, G., Favara, R., Nigro, F., Perticone, M., Renda, P., and Mondello, C. 2006. Integrated neotectonic and morphometric analysis of northern Sicily. Bollettino della Società Geologica Italiana, 125:221-244.

Baldacci, L. 1886. Descrizione geologica dell'isola di Sicilia. Memorie Descrittive della Carta Geologica d'Italia, 1:1-408.

Borghi, E. 1999. Echinodermi fossili dell'Emilia: i Cidaridi del Plio-Pleistocene. Parva Naturalia, 1:105-120.

Borghi, E. 2003. Osservazioni su alcuni Echinodermi del Plio-Pleistocene dell'Emilia. Parva Naturalia, Piacenza, 2:109-124.

Borghi, E. 2012. II genere Spatangus (Echinoidea) nel Langhiano dell'Appennino reggiano. Notiziario della Società Reggiana di Scienze Naturali, (2010):43-61.

Botto Micca, L. 1896. Contribuzione allo studio degli Echinidi terziari del Piemonte. Bollettino della Società Geologica Italiana, 15:341-375.

Bouchet, P. and Taviani, M. 1992. The Mediterranean deep-sea fauna: pseudopopulations of Atlantic species? Deep-Sea Research, 39:169-184.

Bown, P.R. and Young, J.R. 1998. Techniques, p. 16-28. In Bown, P.R. (ed.), Calcareous Nannofossil Biostratigraphy. Kluwer Academic Publ., Dordrecht, The Netherlands.

Bronn, H.G. 1831. Italiens Tertiär-Gebilde und deren organische Einschlüsse. Neue Akademische Buchhandlung von Karl Groos, Heidelberg.

Bukry, D. 1973. Coccolith stratigraphy, eastern equatorial Pacific, Leg 16, Deep Sea Drilling Project. Deep Sea Drilling Project Initial Report 16:653-711.

Castradori, D. 1993. Calcareous nannofossil biostratigraphy and biochronology in eastern Mediterranean deep-sea cores. Rivista Italiana di Paleontologia e Stratigrafia, 99:107-126.

Cavallo, O., Macagno, M., and Pavia, G. 1986. Fossili dell'Albese. Aspetti geologici e paleontologici delle Langhe e del Roero. Famija Albeisa, Savigliano.

Checchia Rispoli, G. 1907. Gli echinidi viventi e fossili della Sicilia. Parte 2: gli Echinidi del piano Siciliano dei dintorni di Palermo. Palaeontographia Italica, 13:199-231.

Checchia Rispoli, G. 1916. Gli echinidi fossili e viventi della Sicilia. Parte 4: Echinidi pliocenici. Palaeontographia Italica, 22:229-242.

Checchia Rispoli, G. 1923. Gli echinidi del pliocene di Anzio. Memorie per servire alla descrizione della Carta Geologica d'Italia, 9:1-29.

Clark, H.L. 1907. The Cidaridae. Bulletin of the Museum of Comparative Zoology at Harvard College, 51:165230.

Clark, H.L. 1912. Hawaiian and other Pacific Echini. The Pedinidae, Phymosomatidae, Stomopneustidae, Echinidae, Temnopleuridae, Strongylocentrotidae and Echinometridae. Memoirs of the Museum of Comparative Zoology at Harvard College, 34:213385. 
Colella, A. and D'Alessandro, A. 1988. Sand waves, Echinocardium traces and their bathyal depositional setting (Monte Torre Palaeostrait, Plio-Pleistocene, southern Italy). Sedimentology, 35:219-237.

Cortese, E. 1882. Brevi cenni sulla geologia della parte N-E della Sicilia. Bollettino del Regio Comitato Geologico d'Italia, serie 2, 3:105-137, 161-189, 308-357.

Cotteau, G. 1877. Description des Echinides, p. 227-335. In Locard, A. (ed.), Description des Faunes des terrains Tertiaires moyen de la Corse, F. Savy Librairie, Paris and H. Georg Libraire, Genève.

Cotteau, G. 1895. Description des échinides recueillis par M. Lovisato dans le Miocène de la Sardaigne. Mémoires de la Société Géologique de France, 13:556.

CSA International, Inc. 2007. Characterization of northern Gulf of Mexico deepwater hard bottom communities with emphasis on Lophelia coral. U.S. Department of the Interior, Minerals Management Service, Gulf of Mexico OCS Region, New Orleans, LA. OCS Study MMS 2007-044. 169 pp.

de Kaenel, E. , Siesser, W.G., and Murat, A. 1999. Pleistocene calcareous nannofossil biostratigraphy and the western Mediterranean sapropels, Sites 974 to 977 and 979, p. 15-183. In Zhan, R., Comas, M.C., and Klaus, A. (eds.), Proceedings of ODP Scientific Results vol. 161, College Station, Texas.

Dela Pierre, F., Piana, F., Fioraso, G., Boano, P., Bicchi, E., Forno, M.G., Violanti, D., Balestro, G., Clari, P., D'Altri, A., De Luca, D., Morelli, M., Ruffini, R., and Polino, R. 2003. Note Illustrative della Carta Geologica d'Italia alla scala 1:50.000, Foglio 157, Trino. APAT - Dipartimento Difesa del Suolo-Servizio Geologico d'Italia. Litografia Geda, Nichiotello, Torino.

Desor, E. 1856. Synopsis des échinides fossiles. Troisième livraison. Reinwald, Paris.

De Stefano, G. 1901. I fossili e la geologia di Capo Milazzo in Sicilia. Atti dell'Accademia Gioenia di Scienze Naturali, serie 4, volume 14, memoria 10:1-23.

Di Geronimo, I., Messina, C., Rosso, A., Sanfilippo, R., Sciuto, F., and Vertino, A. 2005. Enhanced biodiversity in the deep: Early Pleistocene coral communities from southern Italy, 71-86. In Freiwald, A. and Roberts, J.M. (eds.), Cold-water Corals and Ecosystems. Springer-Verlag, Berlin.

Di Stefano, E., Agate, M., Incarbona, A., Russo, F., Sprovieri, R., and Bonomo, S. 2012. Late Quaternary high uplift rates in northeastern Sicily: evidence from calcareous nannofossils and benthic and planktonic foraminifera. Facies, 58:1-15.

Donovan, S.K. and Paul, C.R.C. 1998. Echinoderms of the Pliocene Bowden shell bed, southeast Jamaica. Contributions to Tertiary and Quaternary Geology, 35:129-146.

Donovan, S.K., Portell, R.W., and Veltkamp, C.J. 2005. Lower Miocene echinoderms of Jamaica, West Indies. Scripta Geologica, 129:91-135.
Emery, W.J. 2003. Water Types and Water Masses, p. 1556-1567. In Encyclopedia of Atmospheric Sciences (ed.), Ocean Circulation, Elsevier.

Emig, C.C. and Geistdoerfer, P. 2004. The Mediterranean deep-sea fauna: historical evolution, bathymetric variations and geographical changes. Carnets de Géologie/Notebooks on Geology, Maintenon, Art.2004/01 (CG2004-A01-CCE-PG).

Fell, H.B. 1966. Cidaroids, p. 312-340. In Moore, R.C. (ed.), Treatise on Invertebrate Paleontology, U. Echinodermata 3. Geological Society of America and University of Kansas Press, Lawrence.

Flores, J.A., Gersonde, R., and Sierro, F.J. 1999. Pleistocene fluctuations in the Agulhas current retroflection based on the calcareous plankton record. Marine Micropaleontology, 37:1-22.

Flores, J.A., Gersonde, R., Sierro, F.J., and Niebler, H.S. 2000. Southern ocean Pleistocene calcareous nannofossil events: calibration with isotope and geomagnetic stratigraphies. Marine Micropaleontology, 40:377-402.

Fois, E. 1990a. Stratigraphy and palaeogeography of the Capo Milazzo area (NE Sicily, Italy): clues to the evolution of the southern margin of the Tyrrhenian Basin during the Neogene. Palaeogeography, Palaeoclimatology, Palaeoecology, 78:87-108.

Fois, E. 1990b. La successione neogenica di Capo Milazzo (Sicilia Nord-Orientale). Rivista Italiana di Paleontologia e Stratigrafia, 95:397-440.

Forbes, E. 1841. A History of British Starfishes, and Other Animals of the Class Echinodermata. Samuel Bentley, Bangor House, London.

Freiwald, A. 1998. Geobiology of Lophelia pertusa (Scleractinia) Reefs in the North Atlantic. Habilitation Thesis, University of Bremen, Germany.

Fuglister, F.C. 1954. Average temperature and salinity at a depth of 200 meters in the North Atlantic. Tellus, 6:46-58.

Gaetani, M. and Saccà, D. 1984. Brachiopodi batiali nel Pliocene e Pleistocene di Sicilia e Calabria. Rivista Italiana di Paleontologia e Stratigrafia, 90:407-458.

Garilli, V. 2011. Mediterranean Quaternary interglacial molluscan assemblages: Palaeobiogeographical and palaeoceanographical responses to climate change. Palaeogeography, Palaeoclimatology, Palaeoecology, 312:98-114.

Gartner, S. 1969. Correlation of Neogene planktonic foraminifer and calcareous nannofossil zones. Gulf Coast Association of Geological Societies Transactions, 19:585-599.

Gibbard, P., Head, M.J., Walker, M.J.C., and The Subcommission on Quaternary Stratigraphy. 2010. Formal ratification of the Quaternary System/Period and the Pleistocene Series/Epoch with a base at 2.58 Ma. Journal of Quaternary Science, 25:96-102.

Gray, J.E. 1825. An attempt to divide the Echinida, or sea eggs, into natural families. Annals of Philosophy, new series, 10:423-431. 
Greenstein, B. 1992. Taphonomic bias and the evolutionary history of the family Cidaridae (Echinodermata: Echinoidea). Paleobiology, 18:50-79.

Gvirtzman, Z. and Nur, A. 1999. The formation of Mount Etna as the consequence of slab rollback. Nature, 401:782-785

Harzhauser, M., Kroh, A., Mandic, O., Piller, W.E., Göhlich, U., Reuter, M., and Berning, B. 2007. Biogeographic responses to geodynamics: a key study all around the Oligo-Miocene Tethyan Seaway. Zoologischer Anzeiger, 246:241-256.

Hay, W.W., Mohler, H.P. and Wade, M.E. 1966. Calcareous nannofossils from Nal' chik (northwest Caucasus). Eclogae ,Geologicae Helvetiae 59:379-399.

Hsü, K.J., Ryan, W.B.F., and Cita, M.B. 1973. Late Miocene desiccation of the Mediterranean. Nature, 242:240-244.

Kamptner, E. 1943. Zur Revision der CoccolithineenSpezies Pontosphaera huxleyi Lohm. Anzeiger der Akademie der Wissenschaften in Wien, Mathematische-Naturwissenschaftliche Klasse, 80:43-49.

Kamptner, E. 1950. Über den submikroskopischen Aufbau der Coccolithen. Anzeiger der Akademie der Wissenschaften in Wien, Mathematische-Naturwissenschaftliche Klasse, 87:152-158.

Kamptner, E. 1954. Untersuchungen über den Feinbau der Coccolithen. Archiv für Protistenkunde, 100:1-90.

Kamptner, E. 1963. Coccolithineen-Skelettreste aus Tiefseeablagerungen des Pazifischen Ozeans. Annalen des Naturhistorischen Museums in Wien, 66:139204.

Kidwell, S.M. and Baumiller, T. 1990. Experimental Disintegration of Regular Echinoids: Roles of Temperature, Oxygen, and Decay Thresholds. Paleobiology, 16:247-271.

Kohler, R. 1927. Les Echinodermes des mers d'Europe. Vol. 2, G. Doin, Paris.

Koukouras, A., Sinis, A., Bobori, D., Kazantzidis, S., and Kitsos, M. 2007. The echinoderm (Deuterostomia) fauna of the Aegean Sea, and comparison with those of the neighboring seas. Biological Sciences, Miscellaneous Papers, 7:67-92.

Kroh, A. 2005. Catalogus Fossilium Austriae, Band 2, Echinoidea neogenica. Verlag der Österreichischen Akademie der Wissenschaften, Wien:1-210.

Kroh, A. and Smith, A.B. 2010. The phylogeny and classification of post-Palaeozoic echinoids. Journal of Systematic Palaeontology, 8:147-212.

Lamarck, J.B.P.M. 1816. Histoire naturelle des Animaux sans Vertèbres, présentant les caractères généraux et particuliers de ces animaux, leur distribution, leurs classes, leurs familles, leurs genres, et la citation des principales espèces qui s'y rapportent; précédée d'une Introduction offrant la Détermination des caractères essentiels de l'Animal, sa distinction $d u$ Végétal et des autres corps naturels, enfin, l'exposition des principes fondamentaux de la Zoologie. Vol. 3, Déterville \& Verdière, Paris.
Lambert, J. 1900. Etude sur quelques échinides de l'Infra-Lias et du Lias. Bulletin de la Société des Sciences Historiques Naturelles de l'Yonne, 52 (1899):3-57.

Lambert, J. 1910. Description des échinides des terrains néogènes du Bassin du Rhône. Mémoires de la Société Paléontologique Suisse, 37:1-48.

Lambert, J. and Thiery, P. 1909-1925. Essai de Nomenclature raisonne des échinides. L. Ferriere, Chaumont.

Landi, M. 1929. Gli echinidi neogenici di Montegibbio. Giornale di Geologia, 4:3-22.

La Perna, R. 2003. The Quaternary deep-sea protobranch fauna from the Mediterranean: composition, depth-related distribution and changes. Bollettino Malacologico, 39:17-34.

Laube, G.C. 1869. Die Echinoiden der österreichischungarischen oberen Tertiärablagerungen. Verhandlungen der kaiserlich-königlichen Geologischen Reichsanstalt, jahrgang 1869:182-184.

Lazzarotto, A., Sandrelli, F., Foresi, L.M., Mazzei, R., Salvatorini, G., Cornamusini, G., and Pascucci, V. 2002. Note Illustrative della Carta Geologica d'Italia alla scala 1:50.000, Foglio 295, Pomarance. Servizio Geologico d'Italia. L.A.C., Firenze.

Leske, N.G. 1778. Jacobi Theodori Klein naturalis dispositio Echinodermatum, edita et descriptionibus novisque inventis et synonymis auctorum aucta. Additamenta ad I. T. Klein naturalem dispositionem Echinodermatum. G.E. Beer, Lipsiae.

Linnaeus, C. 1758. Sistema naturae, sive Regna tria Naturae systematicae proposita per Classes, Ordine, Genera et Species (tenth edition), volume 1, Holmiae.

Lipparini, T., Malatesta, A., Nicosia, M., and Valdinucci, A. 1955. Pliocene e Quaternario del Capo Milazzo in Sicilia. Bollettino del Servizio Geologico Italiano, 77:579-604.

Lovén, S. 1874. Etudes sur les Echinoidees. Kongelige Svenska Vetenskaps-Akademiens Handlingar, 11:191.

Maiorano, P., Marino, M., Di Stefano, E., and Ciaranfi, N. 2004. Calcareous nannofossil events in the lowermiddle Pleistocene transition at the Montalbano Jonico section and ODP Site 964: calibration with isotope and sapropel stratigraphy. Rivista Italiana di Paleontologia e Stratigrafia, 110:547-556.

Mariani, E. and Parona, C. 1887. Fossili Tortoniani di Capo San Marco in Sardegna. Atti della Società Italiana di Scienze Naturali, 30:1-153.

Matthews, S.C. 1973. Notes on open nomenclature and synonymy lists. Palaeontology, 16:713-719.

Meneghini, G. 1862. Studi sugli Echinodermi fossili neogenici di Toscana, p. 61-89. In Lazzeri, L. (ed.), Siena e il suo Territorio. Tipografia nel Regio Istituto dei Sordo-Muti, Siena. 
Menesini, E. 1968. Cirripedi, echinidi, elasmobranchi e pesci (s.s.) nel Pliocene di Punta Ristola (Capo di Leuca - Puglia). Atti della Società Toscana di Scienze Naturali, 75:579-596.

Micali, P. and Villari, A. 1989. II deposito fossilifero di Salice (Messina) con particolar riguardo alle specie istituite da Giuseppe Seguenza. Bollettino Malacologico, 25:77-84.

Mortensen, T. 1903. The Danish Ingolf-Expedition. Vol. 4, Echinoidea, part. 1. Bianco Luno, Copenhagen.

Mortensen, T. 1909. Die Echinoiden der Deutschen Südpolar Expedition 1901-1903, p. 1-114. In Drygalski, E. (ed.), Deutschen Südpolar Expedition 1901-1903 im Auftrage des Reichsamtes des Innern, XI. Band, Zoologie III. Band, Heft I.

Mortensen, T. 1910. On some points in the nomenclature of echinoids. Annals Magazine Natural History, Series 8, 5:117-125.

Mortensen, T. 1913. Die Echinodermen des Mittelmeeres. Mitteilungen aus der Zoologischen Station zu Neapel, 21:1-39.

Mortensen, T. 1928. A monograph of the Echinoidea. I. Cidaroidea. Reitzel, Copenhagen.

Mortensen, T. 1943. A monograph of the Echinoidea. III, 3. Camarodonta. A. Reitzel, Copenhagen.

Müller, O.F. 1776. Zoologie Danicae Prodromus, seu Animalium Daniae et Norvegiae indigenarum Characteres, Nomina et Synonyma Imprimis Popularium. Havniae, Typis Hallageriis.

Nebelsick, J.H., Schmid, B., and Stachowitsch, M. 1997. The encrustation of fossil and recent sea-urchin tests; ecological and taphonomic significance. Lethaia 30:271-284.

Ogniben, L. 1957. Petrografia della Serie Solfifera siciliana e considerazioni geologiche relative. Memorie descrittive della Carta Geologica d'Italia, 33:1-257.

Ogniben, L. 1975. Lithostratigraphic complexes and evidence for tectonic phases in Sicily and Calabria. In Ogniben, L., Parotto, M. and Praturlon, A. (eds.), Structural Model of Italy. C.N.R. Quaderni di Ricerca Scientifica, 90:365-408.

Palazzi, S. and Villari, A. 1996. Malacofaune batiali pliopleistoceniche del Messinese. 2: Capo Milazzo. Naturalista Siciliano 20:237-279.

Pérès, J.M. and Picard, J. 1964. Nouveau manuel de bionomie benthique de la mer Méditerranée. Recueil des Travaux de la Station Marine d'Endoume, Faculté des Sciences de Marseille, 31:1-137.

Phelan, T. 1970. A field guide to the Cidaroid Echinoids of north-western Atlantic Ocean, Gulf of Mexico and Caribbean Sea. Smithsonian Contributions to Zoology, 40:1-22.

Philippe, M. 1998. Les échinides miocènes du Bassin du Rhône: révision systématique. Nouvelles Archives du Muséum d'Histoire Naturelle de Lyon, 36(1-2): 3-241, 249-441.
Philippi, R.A. 1845. Beschreibung einiger neuer Echinodermen (Spatangus excavata, Sp. cavernosus, Sp. australia, Sp. placenta, Sp. canaliferus) nebst kritischen Bemerkungen über einige weniger bekannte Arten. Archiv für Naturgeschite, 11:344-359.

Pujos-Lamy, A. 1977. Emiliania et Gephyrocapsa (Nannoplancton calcaire): Biométrie et intérêt biostratigraphique dans le Pléistocène supérieur marin des Açores. Revista Española de Micropaleontología, 9:69-84.

Raffi, I. 2002. Revision of the early-middle Pleistocene calcareous nannofossil biochronology (1.75-0.85 Ma). Marine Micropaleontology, 45:25-55.

Raffi, I. and Rio, D. 1980. Biostratigrafia a nannofossili, biocronologia e cronostratigrafia della serie del Torrente Tiepido (Subappennino Emiliano, Provincia di Modena). Ateneo Parmense, Acta Naturalia, 16:1931.

Raffi, I., Backman, J., Rio, D., and Shackleton, N.J. 1993. Plio-Pleistocene nannofossil biostratigraphy and calibration to Oxygen Isotope stratigraphies from Deep Sea Drilling Project Site 607 and Ocean Drilling Program Site 677. Paleoceanography, 8:387-408.

Reuss, A.E. 1860. Die marinen Tertiärschichten Böhmens und ihre Verseinehrungen. Sitzungsberichte der Kaiserlichen Akademie der Wissenschaften Mathematisch-naturwissenschaftliche Klasse, 39:207-288.

Riedl, R. 1991. Fauna e Flora del Mediterraneo. F. Muzzio, Roma.

Rio, D., Raffi, I., and Villa, G. 1990. Pliocene-Pleistocene calcareous nannofossil distribution patterns in the western Mediterranean, p. 513-533. In Kastens, K.A. et al. (eds.), Proceedings of the Ocean Drilling Propgram Scientific Results, vol. 107, College Station, Texas.

Rogers, A.D. 1999. The biology of Lophelia pertusa (Linnaeus 1758) and other deep-water reef forming corals and impacts from human activities. International Review of Hydrobiology, 844:315-406.

Ruggieri, G. 1967. The Miocene and later evolution of the Mediterranean Sea, p. 283-290. In Adams, C.G. and Ager, D.V. (eds.), Aspects of Tethyan Biogeography. Systematics Association Publications, Oxford, UK.

Ruggieri, G. and Greco, A. 1965. Studi geologici e Paleontologici su Capo Milazzo con particolare riguardo al Milazziano. Geologica Romana, 4:41-88.

Sato, T. and Takayama, T. 1992. A stratigraphically significant new species of the calcareous nannofossil Reticulofenestra asanoi, p. 457-460. In Ishizaki, K and Saito, T. (eds.), Centenary of Japanese Micropaleontology. Terra Scientific, Tokyo.

Scilla, A. 1670. La vana speculazione disingannata dal senso. Lettera risponsiva circa i Corpi Marini che Petrificati si trovano in varij luoghi terrestri. Andrea Colicchia, Napoli. 
Scilla, A. 1747. De corporibus marinis lapidescentibus quae de fossa reperiuntur. Typis Antonii de Rubeis, Romae.

Sciuto, F. 2003. Dati preliminari sulla ostracofauna pliocenica di Capo Milazzo (Sicilia NE). Bollettino della Società Paleontologica Italiana, 42:179-184.

Sciuto, F. and Rosso, A. 2008. Distribution pattern of deep-water ostracod assemblages within lower Pleistocene sediments from Furnari (Sicily). Bollettino della Società Paleontologica Italiana, 47:33-43.

Seguenza, G. 1873-77. Studi stratigrafici sulla formazione pliocenica dell'Italia meridionale. Bollettino del Regio Comitato Geologico d'Italia, 4-8:299 pp.

Serafy, D.K. 1979. Echinoids (Echinodermata: Echinoidea). Memoirs of the Hourglass Cruises, 5(3):120 pp.

Shäfer, W. 1972. Ecology and Palaeoecology of Marine Environments. The University of Chicago Press, Chicago.

Simonelli, V. 1889. Terreni e fossili dell'isola di Pianosa nel mar Tirreno. Bollettino del Reale Comitato Geologico Italiano, serie 2, volume 10:193-237.

Sismonda, E. 1842. Appendice alla monographia degli Echinidi fossili del Piemonte. Memorie della Reale Accademia delle Scienze di Torino, volume 4, serie 2:385-397.

Smith, A.B. 1978. A functional classification of the coronal pores of regular echinoids. Palaeontology, 21:759-789.

Smith, A.B. 1984. Echinoid Palaeobiology. Special topics in palaeontology. Harper Collins Publishers Ltd, London.

Smith, A.B. and Gale, A. 2009. The pre-Messinian deepsea Neogene echinoid fauna of the Mediterranean: Surface productivity controls and biogeographical relationships. Palaeogeography, Palaeoclimatology, Palaeoecology. 281:115-125.

Smith, A.B. and Kroh, A. (eds.) 2011. The Echinoid Directory. World Wide Web electronic publication. http://www.nhm.ac.uk/research-curation/projects/ echinoid-directory [accessed May, 10, 2013].

Sprovieri, R. 1985. Paleoecological results from foraminiferal assemblage at the top of the Sicilian stratotypesection (Ficarazzi, Palermo, Italy). Bollettino della Società Paleontologica Italiana, 24:3-11.
Stefanini, G. 1908. Echinidi del Miocene medio dell'Emilia (Parte prima). Palaeontographia Italica, 14:65120.

Taviani, M. 2002. The Mediterranean benthos from late Miocene up to present: ten million years of dramatic climatic and geologic vicissitudes. Biologia Marina Mediterranea, 9:445-463.

Thierstein, H.R., Geitzenauer, K., Molfino, B., and Shackleton N.J. 1977. Global synchroneity of late Pleistocene coccolith datum levels; validation by oxygen isotopes. Geology, 5:400-404.

Thomson, C.W. 1872. On the Echinoidea of the "Porcupine" Deep-sea Dredging-Expeditions. (Abstract). Proceedings of the Royal Society of London, 20:491497.

Tortonese, E. 1965. Fauna d'ltalia. Echinodermata. Calderini, Bologna.

Tortonese, E. 1977. Recenti acquisizioni e rettifiche intorno ai Crinoidi, Oloturoidi, Ofiuroidi ed Echinoidi del Mediterraneo. Atti Società Italiana di Scienze Naturali, 118:333-352.

Vazzana, A. 1996. Malacofauna batiale del Pleistocene inferiore del Vallone Catrica (Reggio Calabria, Italia). Bollettino Malacologico, 31:143-162.

Vertino, A. 2004. Esacoralli Plio-Pleistocenici e attuali del Mediterraneo (sistematica, biostratinomia, paleoecologia). Paleo Italia, 10:22-25.

Vinassa de Regny, P.E. 1897. Echinidi neogenici del Museo parmense. Atti della Società Toscana di Scienze Naturali, 15:1-19.

Violanti, D. 1988. I foraminiferi plio-pleistocenici di Capo Milazzo. Bollettino del Museo Regionale di Scienze Naturali di Torino, 6:359-392.

Weaver, P.P.E. and Thomson, J. 1993. Calculating erosion by deep-sea turbidity currents during initiation and flow. Nature, 364:136-138.

Wei, W. 1993. Calibration of Upper Pliocene-Lower Pleistocene nannofossil events with Oxygen Isotope stratigraphy. Paleoceanography, 8:85-99.

Wright, T. 1864. On the fossil Echinidae of Malta. Quarterly Journal of the Geological Society of London, 20:471-491. 